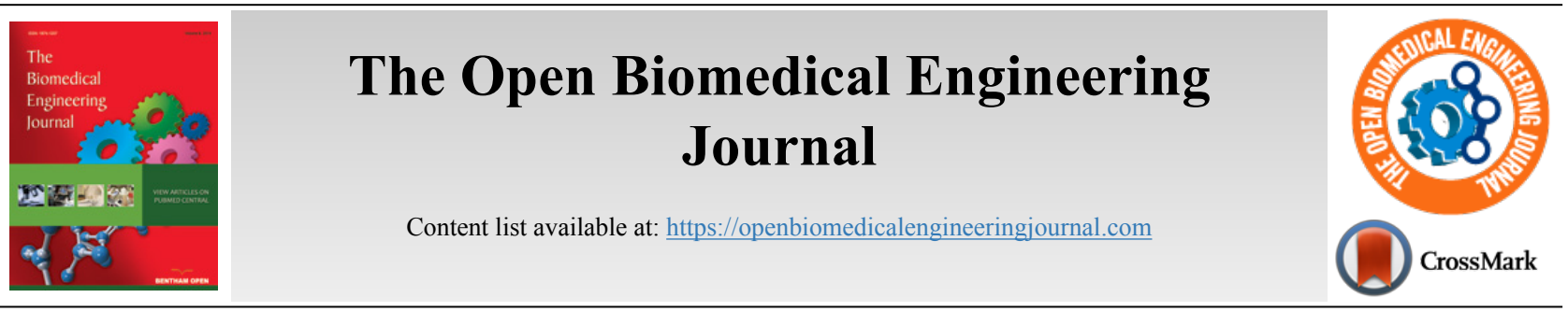

REVIEW ARTICLE

\title{
Physiological Microenvironmental Conditions in Different Scalable Culture Systems for Pluripotent Stem Cell Expansion and Differentiation
}

\author{
Fuad G. Torizal ${ }^{1, *}$, Ikki Horiguchi ${ }^{2}$ and Yasuyuki Sakai ${ }^{2,3}$ \\ ${ }^{1}$ Department of Bioengineering, Graduate School of Engineering, The University of Tokyo, Tokyo, Japan \\ ${ }^{2}$ Department of Chemical Systems Engineering, Graduate School of Engineering, The University of Tokyo, Tokyo, Japan \\ ${ }^{3}$ International Research Center on Integrative Biomedical Systems CIBiS, Institute of Industrial Science, The University of Tokyo, Tokyo, Japan
}

\begin{abstract}
Human Pluripotent Stem Cells (PSCs) are a valuable cell type that has a wide range of biomedical applications because they can differentiate into many types of adult somatic cell. Numerous studies have examined the clinical applications of PSCs. However, several factors such as bioreactor design, mechanical stress, and the physiological environment have not been optimized. These factors can significantly alter the pluripotency and proliferation properties of the cells, which are important for the mass production of PSCs. Nutritional mass transfer and oxygen transfer must be effectively maintained to obtain a high yield. Various culture systems are currently available for optimum cell propagation by maintaining the physiological conditions necessary for cell cultivation. Each type of culture system using a different configuration with various advantages and disadvantages affecting the mechanical conditions in the bioreactor, such as shear stress. These factors make it difficult to preserve the cellular viability and pluripotency of PSCs. Additional limitations of the culture system for PSCs must also be identified and overcome to maintain the culture conditions and enable large-scale expansion and differentiation of PSCs. This review describes the different physiological conditions in the various culture systems and recent developments in culture technology for PSC expansion and differentiation.
\end{abstract}

Keywords: Pluripotent stem cells, Culture systems, Mechanical stress, Microenvironmental condition, Mass production, Bioreactor.

\begin{tabular}{l|l|l|l} 
Article History & Received: October 31, 2018 & Revised: January 26, 2019 & Accepted: February 6, 2019
\end{tabular}

\section{INTRODUCTION}

Human Pluripotent Stem Cells (PSCs) exhibits decent selfrenewal and differentiation capability into various cell types consisted of the human body. They show remarkable promise for clinical applications and novel strategies in regenerative medicine, drug discovery, and in vitro toxicology for clinical and industrial purposes. The target organs of these technologies vary widely from small organs such as retinal tissue [1] to large organs such as the heart [2], pancreas [3], and liver [4].

For all of these applications, a sufficient quality and quantity of PSCs are needed, which can be generated in scalable three dimensional (3D) culture system that supports a larger density of cell culture and higher growth rate with good manufacturing practice-compatible, simple, and easy to automate [5 - 8]. Although numerous research groups have attempted to develop optimum culture systems for PSCs, the currently available culture systems show some limitations, such as difficulties in scaling up, automation, and standardization.

\footnotetext{
* Address correspondence to this author at the Department of Bioengineering, Graduate School of Engineering, The University of Tokyo, 7-3-1, Hongo, Bunkyo-Ku, Tokyo, Japan; Tel: +81-3-5841-7032; Fax: +81-3-5841-7032; E-mail: t_gandhi@chemsys.t.u-tokyo.ac.jp
}

Therefore, the effectiveness of these scalable culture technology for PSC expansion and differentiation must be improved.

Here, we introduce the advantages and remaining disadvantages of various culture systems for PSCs mass production and differentiation. In addition, we describe the important microenvironmental conditions required to optimize PSCs mass production systems development as a consideration when selecting, combining, or modifying various culture systems.

\section{PLURIPOTENT STEM CELL TYPES}

Generally, PSCs can be derived from embryonic or adult tissue and are classified as Embryonic Stem Cells (ESCs) or induced Pluripotent Stem Cells (iPSCs), respectively.

ESCs were firstly isolated from the inner cell mass of blastocysts by Thomson et al. in 1998 [9]. ESCs have some disadvantages, such as the requirement to extract and manipulate the embryo, which is limited by ethical considerations. In clinical use, because ESCs are derived from embryonic stage cells, it is more difficult to obtain immunocompatible cells for transplantation. This increases the risk of immune rejection in allogeneic transplantation. To overcome this limitation, immunosuppression or immuno- 
isolation such as encapsulation is necessary when ESCs are administered into a recipient's body. These techniques have been applied in some clinical trials, such as to encapsulate insulin-producing cells from human ESCs during pancreatic regeneration [10].

iPSCs were firstly generated by Yamanaka et al. in 2006 $[11,12]$. Adult somatic cells were reprogrammed into pluripotent cells by overexpressing transcription factors Oct4, Sox2, Klf- 4 and c-Myc via transfection into human fibroblasts [13 - 14]. This achievement is very promising for both regenerative medicine and industrial-related applications such as drug screening. iPSCs not only show similar characteristics such as remarkable pluripotency to ESCs but also present minimum ethical issues such as those involving embryo destruction for ESCs [5, 15, 16]. Moreover, this technology provides the opportunity to generate iPSCs from patients via tissue biopsy, which may minimize immune rejection by using autologous transplantation. In contrast, this reprogramming technology also has drawbacks. The integration of the transcription factor into cells genome can cause an unwanted effect. For instance, the insertion of proto-oncogene like c-myc increases the risk of tumor formation [17]. Currently, numerous studies were attempted to resolve this problem with nonintegrating methods [17 - 25]. However, most of the results show a lack of reprogramming efficiency when compared to integrating methods.

\section{DEVELOPMENT OF PSCS CULTURE}

The first method for the large-scale production of animal cells was developed for baby hamster kidney cells by Capstick et al. in 1962 [26, 27]. This technology has been applied to a broad range of biological products, such as monoclonal antibodies, hormones, vaccines, and other pharmaceutical products [28]. In PSC cultivation, the purpose of mass production is to prepare a large number of cells for industrial and clinical use. For example, pancreatic islet transplantation requires at least $6 \times 10^{8}$ beta cells which derived from an approximately $0.6 \mathrm{~m}^{2}$ of culture area; this corresponds to 600 6 -well plates [29]. To regenerate $30 \%$ of liver tissue, $6 \times 10^{10}$ liver cells are required, covering $60 \mathrm{~m}^{2}$ of culture area or 60,000 6-well plates [30]. To obtain the high-quality cells for these applications, it is important to sustain the self-renewal properties, maintain the pluripotency, and provide cryopreservation to maintain established cultures by using proper microenvironment for cell growth [31].

Selection of the culture system for PSCs largely depends on their cellular characteristic during cultivation (Table 1). In all culture methods, a single hPSC is known to undergo apoptosis without Rho-associated protein kinase (ROCK) inhibition. These conditions are thought to be caused by anoikis, the apoptosis mechanism induced by a lack or alteration of cell-cell or cell-matrix interactions [32]. When hPSCs dissociated into single cells, the loss of E-cadherin, a key molecule in intercellular adhesion, can activate the ROCKdependent signaling cascade to induce myosin hyperactivation. These cascades can increase myosin contraction, impacting cellular vulnerability and causing apoptosis [33 - 35]. Thus, hPSCs are typically seeded as clusters or single cells with ROCK inhibitors such as Y-27632 and HA-1077 [36, 37]. Adherent culture is the most widely used method for culturing undifferentiated PSCs. However, they can also be cultured in suspension as single cells or aggregates [38].

The extracellular signaling is also important to maintain the state of pluripotency. Several study revealed several signaling molecule such as Transforming Growth Factor beta 1 (TGF- $\beta 1$ ) [39, 40], activin A [39, 41, 42], bone morphogenetic protein 4 (BMP-4) [43, 44], Fibroblast Growth Factor 2 (FGF2) [45], Leukemia Inhibitory Factor (LIF) [43], and Nodal $[39,46]$. In order to provide the required amount to keep their self-renewal, these molecules were regularly supplemented in the culture medium.

Table 1. Possible combined culture techniques in various PSCs culture systems.

\begin{tabular}{|c|c|c|}
\hline PSCs Type & Possi & \\
\hline \multirow{4}{*}{ Adherent } & Static Culture Systems & Automation \\
\hline & Hollow fiber bioreactor & $\begin{array}{c}\text { Scaffold } \\
\text { Perfusion } \\
\text { Automation }\end{array}$ \\
\hline & Stirred culture systems & $\begin{array}{c}\text { Microcarrier } \\
\text { Cell encapsulation } \\
\text { Perfusion } \\
\text { Automation } \\
\end{array}$ \\
\hline & Rotary culture systems & $\begin{array}{c}\text { Microcarrier } \\
\text { Cell encapsulation } \\
\text { Perfusion } \\
\text { Automation }\end{array}$ \\
\hline \multirow{2}{*}{ Suspension } & Stirred culture systems & $\begin{array}{c}\text { Aggregates culture } \\
\text { Cell encapsulation } \\
\text { Perfusion } \\
\text { Automation } \\
\end{array}$ \\
\hline & Rotary culture systems & $\begin{array}{c}\text { Aggregates culture } \\
\text { Cell encapsulation } \\
\text { Perfusion } \\
\text { Automation } \\
\end{array}$ \\
\hline
\end{tabular}




\subsection{Adherent Culture Methods}

Adherent culture is the most widely used cell culture method for biological studies. For adherent PSCs, the interactions between PSCs and feeder cells are essentially required to provide support, such as producing secreted growth factor, expressing specific ligands, releasing cytokine, and providing the cell-cell interaction for stable attachment which is important for the cell growth and pluripotency [47, 48]. Several proteins which required for maintaining the pluripotency, such as Transforming Growth Factor beta 1 (TGF- $\beta 1$ ) [49], activin A [49], bone morphogenetic protein (BMP)-4 [49], Fibroblast growth factor 2 (FGF2) [49], and Wnt-3 [50] were secreted by the feeder cells.

Inactivated mouse embryonic fibroblasts are traditionally used as a supportive feeder layer to sustain hPSC propagation $[15,51,52]$. However, co-culturing PSCs with animal feeder cells present the transmission of unwanted genes, viral contaminations, or immunogenic nonhuman saccharides such as sialic acid [53], as well as variability in experimental results [54]. To overcome these limitations, many studies have developed xeno-free human feeder cells, such as human foreskin fibroblasts $[49,55,56]$ human adipose-derived stromal cells $[57,58]$, amniotic epithelial cells [59,60], fetal skin cells [61, 62], and amniotic Mesenchymal Stem Cells (MSCs) [63]. Autologous adult human fibroblasts are preferably used as feeder cells in clinical applications because they minimize xenogeneic substances from animals and are easy to obtain. Moreover, human PSCs can be generated from isogenic parental cells as feeder cells, and thus the compatibility of cell-cell interactions can be better maintained [64]. However, maintenance in the culture systems using feeder cells is costly and time-consuming.

Therefore, in large-scale culture, the application of feeder layer can be eliminated to obtain a higher yield and reduce production costs [65]. Alternatively, feeder cells can be replaced with a conditioned medium and Extracellular Matrix ( ECM), such as Matrigel [66], fibronectin [66], laminin [67 - 69], and vitronectin [70], which are normally produced by feeder cells to maintain the PSCs in culture. The medium consists of non-xenogeneic compounds that are also essentially required for the propagation and differentiation of hPSCs used in clinical applications. In addition, the growth factor such as such as activin A, TGF- $\beta 1$, FGF2, Insulin, Transferrin, and Nodal also added in the medium formulation to support the proliferation and reconstitute its production from the feeder cells [70]. Currently, feeder cell-conditioned media or commercially available synthetic media for feeder-free culture have been used for PSCs culture. Media selection varies depending on the cell type and it is necessary to optimize the media conditions for different culture methods and cells $[7,71,72]$.

To harvest PSCs, the conventional adherent method requires cell removal by mechanical or enzymatic separation, which may damage the cells and affect the quality and quantity of mass-produced PSCs [73]. These conditions make the use of human PSCs for clinical applications which were more difficult to achieve.

\subsection{Suspension Culture Methods}

Current development in cell culture technology has enabled adherent PSCs to be adapted for suspension culture. This method can provide a better mass transfer of nutrition and does not require enzymatic or physical removal, which can disrupt the cell membrane. Elimination of the feeder layer and synthetic matrices can simplify the procedure and minimize contamination. In industrial applications, this system can also increase the scalability by enabling high-density cell culture ( $>$ $1 \times 10^{7}$ cells $/ \mathrm{mL}$ ) and significantly reducing the costs involved [28]. A recent experimental study revealed that global gene expression, mainly the pluripotency gene and functional characteristics, were comparable to those maintained under adherence conditions $[74,75]$. Differentially expressed genes between suspension and adherent PSCs culture were mainly associated with cellular adhesion and extracellular matrix interactions $[74,76]$. In addition, the 3D structure also shows better performance in differentiation in comparison with adherent culture based-differentiation. This phenomenon occurred because of the lack of interaction between PSCs in adherent culture [77].

\section{MECHANICAL AND PHYSIOLOGICAL ENVIRONMENT IN BIOREACTOR SYSTEMS FOR PSCS EXPANSION AND DIFFERENTIATION}

The bioreactor system provides expandable culture volume and dynamic physiological environment compared to conventional dish culture [78]. Ideally, bioreactor systems for PSC cultivation should meet several essential requirements, such as efficient mass transfer of oxygen and nutrients, waste transfer, and minimum shear stress [79]. These microenvironmental factors may affect cell pluripotency and fate during differentiation. Depending on the utilization, optimal PSCs expansion or differentiation can be conducted under various conditions (Table 2).

Generally, in the culture systems, PSCs are incubated at $37^{\circ} \mathrm{C}$ and $\mathrm{pH}$ 7.4. The instability of these culture conditions can inhibit cell proliferation, reduce pluripotency, and decrease cell viability $[80,81]$. One of the main limiting factors in PSCs culture is the low $\mathrm{pH}$ which is mostly caused by the accumulation of secreted lactate in culture medium $[45,82$, 83]. This condition occurred because of it's higher glycolysis rate and cell cycle profile when compared to adult somatic cells, impacted to higher lactate secretion than glucose consumption [82, 84]. Therefore, the continuous removal of lactate is necessarily required in PSCs culture system.

Viscosity is correlated with fluid movement in culture systems. Appropriate medium viscosity properties are required to maintain the proper PSCs culture. Medium with lower viscosity exhibits more rapid mass transfer and uniform conditions in mass production. In contrast, a previous study showed that human PSCs culture in less viscous media may cause cell agglomeration and shear-induced apoptosis, leading to lower yields [8]. In addition, a recent study showed that the culture medium which exhibit continuous viscoelasticity by using an optimized non-toxic polymer, such as low acyl gellan gum can form large numbers of uniformly sized aggregates and maintain cells in a suspension without agitation, is one prom- 
Table 2. Comparison and example of various culture systems application for PSCs expansion and differentiation. The (*) mark showing the remaining disadvantage which need to be overcome.

\begin{tabular}{|c|c|c|c|c|c|c|c|c|}
\hline \multicolumn{2}{|c|}{ Culture Systems } & \begin{tabular}{|r|} 
Ease of \\
Scale Up
\end{tabular} & $\begin{array}{c}\text { Ease of } \\
\text { Monitoring }\end{array}$ & \begin{tabular}{|c|} 
Ease of \\
Harvesting
\end{tabular} & $\begin{array}{l}\text { Mass } \\
\text { Transfer }\end{array}$ & $\begin{array}{l}\text { Shear } \\
\text { Stress }\end{array}$ & $\begin{array}{l}\text { References of Application in } \\
\text { PSCs Expansion }\end{array}$ & \begin{tabular}{|c|} 
References of \\
Application in PSCs \\
Differentiation Types
\end{tabular} \\
\hline \multirow{5}{*}{$\begin{array}{l}\text { General } \\
\text { culture } \\
\text { systems }\end{array}$} & $\begin{array}{l}\text { Conventional } \\
\text { static culture }\end{array}$ & low* & low* & high & low* & low & $\begin{array}{l}\text { hiPSCs[52,148,149], hESCs[52], } \\
\text { miPSCs[150], mESCs[151] }\end{array}$ & $\begin{array}{c}\text { Hepatocyte [152], } \\
\text { chondrocytes [153], } \\
\text { muscle fiber cells [154], } \\
\text { lung and thyroid } \\
\text { progenitor cells [155], } \\
\text { odontoblast [156], } \\
\text { cardiomyocytes [157] }\end{array}$ \\
\hline & Automation & medium & high & high & low* & low & $\begin{array}{c}\text { hiPSCs }[106,110,158-160], \\
\text { hESCs [161], mESCs [160], } \\
\text { miPSCs [162] }\end{array}$ & $\begin{array}{l}\text { Cardiomyocyte }[159] \\
\text { neural cells }[160]\end{array}$ \\
\hline & $\begin{array}{l}\text { Stirred } \\
\text { bioreactor }\end{array}$ & high & high & high & high & high* & $\begin{array}{c}\text { hiPSCs } \\
\text { [97,113,114,148,163,164], } \\
\text { hESCs }[97,114], \text { miPSCs }[165]\end{array}$ & \begin{tabular}{|c|} 
Hepatocyte $[123]$, \\
cardiomyocytes \\
{$[122,166,167]$,} \\
pancreatic $\beta$ cells $[168]$, \\
Endothelial cells $[169]$ \\
\end{tabular} \\
\hline & Rotary bottle & medium & medium & high & high & medium & mESCs [170], hESCs [171] & $\begin{array}{c}\text { Cardiomyocyte } \\
{[127][166], \text { osteogenic }} \\
\text { cells }[170] \\
\end{array}$ \\
\hline & $\begin{array}{c}\text { Hollow fiber } \\
\text { bioreactor }\end{array}$ & medium & low* & low* & medium & low & mESCs [172], hESCs [131] & $\begin{array}{c}\text { Hepatocyte } \\
{[129,130,173]}\end{array}$ \\
\hline \multirow{2}{*}{$\begin{array}{c}\text { Other } \\
\text { culture } \\
\text { techniques }\end{array}$} & Microcarrier & high & low* & low* & medium & high* & $\begin{array}{l}\text { mESCs [174], hESCs [175], } \\
\text { hiPSCs [175] }\end{array}$ & $\begin{array}{c}\text { Neural progenitor [176], } \\
\text { endoderm progeny } \\
{[177], \text { hematopoetic }} \\
\text { cells [178], hepatocytes } \\
{[179], \text { cardiomyocytes }} \\
{[168,180,181] .} \\
\end{array}$ \\
\hline & $\begin{array}{c}\text { Cell } \\
\text { encapsulation }\end{array}$ & medium & low* & low* & medium & low & $\begin{array}{c}\text { miPSCs [145], mESCs } \\
{[142,146], \text { hESCs }[141,182]}\end{array}$ & $\begin{array}{c}\text { Cardiomyocyte } \\
\text { [143], pancreatic } \\
\text { cells [183], } \\
\text { definitive endoderm } \\
\text { [182], osteogenic } \\
\text { cells [170] }\end{array}$ \\
\hline
\end{tabular}

ising culture strategy [85]. However, scaling up of this method results in the limited mass transfer of oxygen and nutrients.

Oxygen is one of the most important components in cell culture systems and it is involved in nearly all cellular aerobic metabolic cycles. In PSCs propagation, the concentration of oxygen in the culture media is a crucial factor in pluripotency and proliferation that maintains their cellular characteristics [86]. An in vitro study clearly demonstrated that differentiation was significantly reduced in human ESCs under hypoxic culture conditions $\left(1-5 \% \mathrm{O}_{2}\right)$ compared to its culture under normoxic conditions $\left(21 \% \mathrm{O}_{2}\right)$ by morphologically distinct growth area examination and expression of pluripotency markers according to biochemical and immunohistology assays [84, 87]. Another study showed that hypoxia of iPSCs cultivated under $5 \% \mathrm{O}_{2}$ improved the efficiency of iPSC proliferation and enhanced the expression levels of transcription factors for iPSC reprogramming (Oct $3 / 4$ and Nanog), which are required to maintain pluripotency [88]. Repeated passaging of hESCs under normoxic culture conditions resulted in an increased number of differentiated cells and reduced self-renewal [89]. ESC growth under hypoxic conditions can preserve the pluripotency during repeated passaging and able to promote the formation of embryoid bodies after random differentiation [87]. Forsyth et al. reported that physiologic oxygen $(2 \%)$ may reduce chromosomal damage and induce recovery after oxidative damage post room oxygen $(20 \%)$ treatment [90]. These studies clearly showed that oxygen concentration affects PSC growth, differentiation, and EB formation. In this regards, the PSCs can be maintained or expanded in hypoxia condition and it can gradually switch into normoxia condition in a certain stage when the differentiation was performed. For example, the different oxygen concentration can be applied in hepatic differentiation by mimicking the original liver development during embryogenesis [91]

Cell aggregation control is very important for maintaining PSCs in an undifferentiated state and preserving cellular viability. In suspension hPSC propagation in vitro, cell-cell interactions are essentially required. Therefore, PSCs must grow in appropriate-sized aggregates. A recent study demonstrated that excess aggregation can direct PSCs into spontaneous differentiation, which occurred as the size of PSCs aggregates increased [92 - 95]. Moreover, insufficient oxygen and nutrition exposure can result in necrotic cells in the center of the aggregates [96]. Some approaches for controlling aggregation in suspension culture have been reported. Culturing in a microwell is one of the most widely used technologies for controlling aggregation. Seeded cells are 
divided and form a single aggregate in each microwell, resulting in the reproducible growth of uniform aggregates with high efficiency. However, the culture operations are still difficult to control because the high medium flow can be resulted from strong flow during culture medium changes, causing aggregates to detach from the microwell and fused each other. Therefore, it is technically required gentle treatment during medium removal or addition. Alternatively, to control these aggregations in suspension culture, dynamic conditions can be applied in the bioreactor system by adding impeller agitation of the culture media, but as an adverse effect, excessively high shear stress causes cell death and spontaneous differentiation $[97,98]$. One of recently developed method for controlling aggregation is the addition of lipid-rich albumins, such as Albumax. This compound can reduce aggregation by inhibiting E-cadherin-mediated cell-cell attachment. A previous study showed that $0.2-0.5 \%$ Albumaxin the culture medium is the optimal concentration for obtaining appropriately sized aggregates and higher hiPSC yields in 12-well plates in well-preserved pluripotency [99].

Shear stress is a particularly important biomechanical factor in mammalian cell culture. Most of the cell types respond to shear stress by physiological or gene expression alterations [100, 101]. Generally, excess hydrodynamic stress by vigorous agitation can decrease the viability of mammalian cells [76, 102]. In addition, excess agitation during cultivation may affect the phenotype and characteristics of PSCs. For example, an excessive centrifugal force of $1000 \times g$ or more

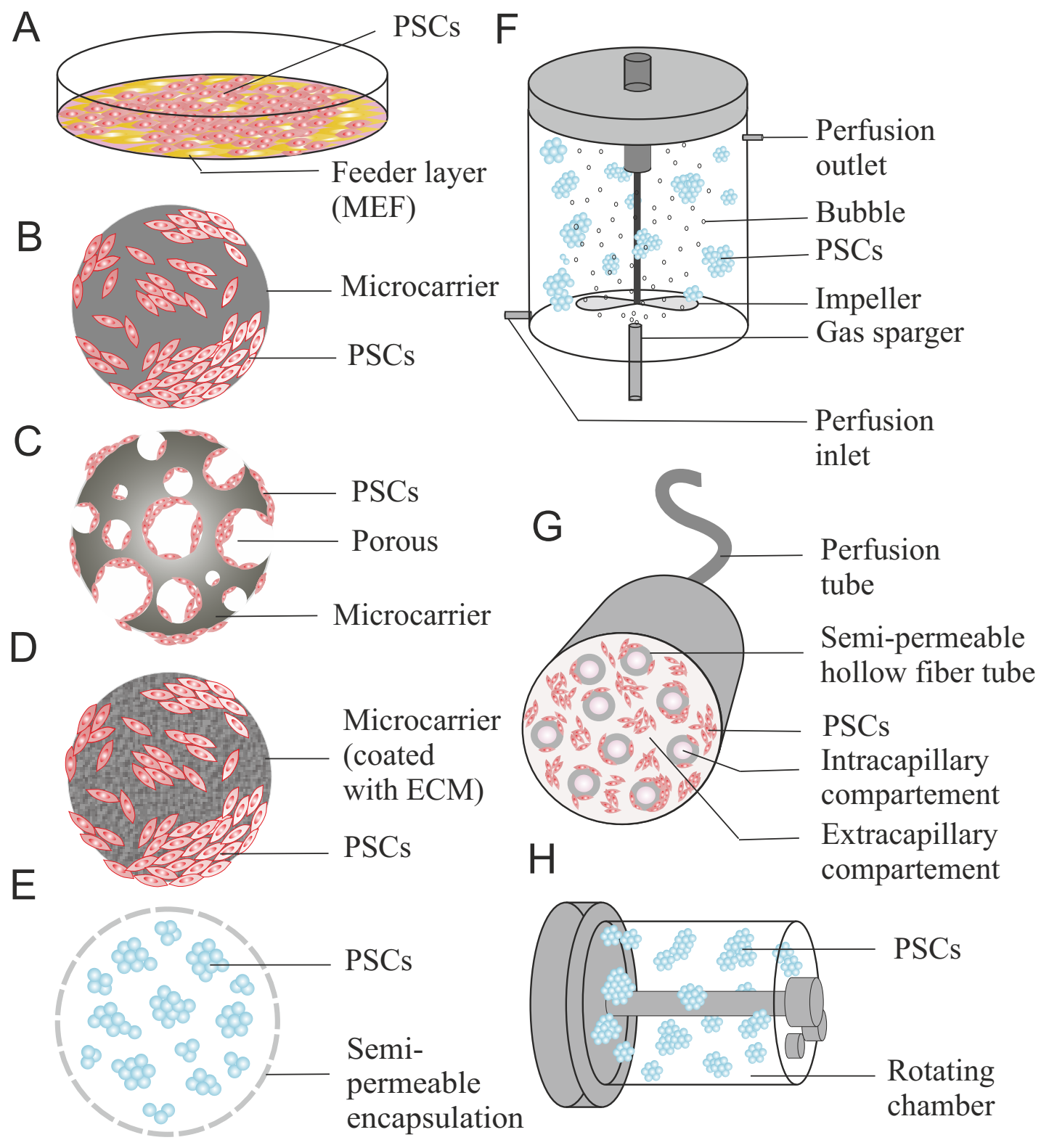

Fig. (1). Different culture systems in PSCs cultivation: 2D static culture (A), solid filled-microcarrier (B), porous microcarrier (C), coated microcarrier (D), cell encapsulation (E), stirred bioreactor (modified by oxygen sparger and perfusion systems) (F), hollow fiber systems (G), and rotary culture systems $(\mathbf{H})$. 
may induce phenotypical shifting and decrease the proliferation rate during expansion [80]. A study conducted by Sargent et al. revealed that exposure to hydrodynamic stress conditions not only significantly affected aggregates formation and structure, but also induced downregulation of pluripotency genes, resulting in spontaneous differentiation [103]. Moreover, in the suspension culture systems, cells in aggregates are exposed to higher shear stress than individual cells because of their large particle diameter [104].

\section{CULTURE SYSTEMS IN PSC MASS PRODUCTION}

\subsection{PSC Adhesion Culture Systems}

Conventionally, PSCs are cultured in tissue culture dishes (Fig. 1A), multiwell plates, and tissue culture flasks. These methods provide two-dimensional surfaces for the growth of PSCs. Under these two-dimensional conditions, morphological examination of PSCs in colonies or as single cells can be more easily observed by direct visualization using a microscope, which is important for monitoring both undifferentiated PSCs or changes in PSC shape during various stages of differentiation. These disposable systems are also relatively simple, easy to handle, and inexpensive. However, in large-scale PSC production, this system represents several disadvantages, such as a limited surface area (approximately $2-225 \mathrm{~cm}^{2}$ working area), which is required for adherent cells. This condition makes the scaling up difficult. Furthermore, the static conditions of the culture can cause poor mixing of the medium, leading to concentration gradients in PSCs culture [38]. Because of these gradients, controlling parameters such as temperature, $\mathrm{pH}$, and dissolved $\mathrm{O}_{2}$ is challenging in adhesion culture systems. Multiple plates or flasks (or flasks with multiple trays) are required to obtain large numbers of cells simultaneously, but these vessels also require repeated extensive handling for feeding and subculturing, making the process more laborious and prone to contamination [105]. In addition, the considerable amount of these disposable plastic materials waste can cause an environmental problem.

To overcome the difficulty of handling, an automated culture system has been developed by utilizing a machine, robotics, and programming to conduct cell propagation. Automation systems show many benefits, such as the ability to significantly reduce the working time for the technician, provide automated and scheduled screening, imaging, or cell maintenance based on cell growth, and minimize the risk of contamination [106, 107]. Most of the commercially available automated culture systems, such as Cytogration ${ }^{\mathrm{TM}}$ systems, SelecT ${ }^{\mathrm{TM}}$ systems, and AcCelerator ${ }^{\mathrm{TM}}$ systems, are based on continuous cell maintenance, which automatically delivers media containing nutrients and removes cellular waste products [108]. They also allow for periodic automated evaluation, such as to detect the $\mathrm{pH}$, nutrition and waste concentrations, cell growth rate, and cellular viability [109]. These systems provide more consistent data regarding the culture procedure [109]. Soares et al. established a protocol for maintaining hiPSCs using feeder-free and chemically defined media on the inCompacTSelec $\mathrm{T}^{\mathrm{TM}}$ automation platform without significantly decreasing pluripotent capabilities [110]. Current automated culture technology, such as CellCelector also equipped with cell sorting combined with a cell scrapping module to selectively harvest the PSCs colony from feeder cells [111].

\subsection{PSC Suspension Culture Systems}

\subsubsection{Stirred Bioreactor}

A stirred bioreactor is one of the most common types of bioreactor systems used to cultivate PSCs on a large scale. This culture system provides a homogeneous environment for the expansion of ESCs and iPSCs by continuous agitation in large working volumes $(50 \mathrm{~mL}-200 \mathrm{~L})[5,112,113]$ (Fig. 1F). Various types of feeding operations such as batch, fed-batch, or perfusion have been developed. In these culture systems, PSCs are cultured as aggregates or adherent colonies combined with various $3 \mathrm{D}$ cell culture technology, such as microcarrier, cell encapsulation, or scaffold. The combination of culture techniques may enhance scalability, improve oxygen and mass transfer, and ease complicated handling. In addition, this bioreactor is controllable by installing sensors to detect $\mathrm{pH}$, dissolved $\mathrm{O}_{2}$, medium level, and temperature [114].

The stirred bioreactor mainly using an agitation mechanism with an impeller or stirrer to obtain a uniform culture mixture. In suspension culture, this agitation is important for maintaining pluripotency. A previous study evaluated various levels of shear in a stirred suspension bioreactor to determine its ability to maintain aggregate size. The results showed that the higher level of shear force in the suspension bioreactor produced smaller hESC and hiPSC aggregates compared to lower shear force [114]. On the other hand, excessive mechanical agitation can produce high shear stress, which can harm PSCs by affecting their pluripotency and viability [114 - 117]. Such damage can be relieved by decreasing the rotational speed, modifying the shape and size of the impeller, or by adding additional substances, such as bovine serum albumin, to protect the cells from shear stress.

In some bioreactors, installation of a gas sparger can accelerate gas transfer and increase hydrodynamic movement. However, the bubbles produced by the gas sparger may potentially harm the cells. These bubbles rise faster than the medium flow and slowly carry the cells to the surface, increasing the shear stress to the cell membrane [118]. This condition was previously demonstrated by microfluidic assessment, which mimics bubble-induced shear stress, in Chinese hamster ovary cells [119]. In addition, bubble accumulation can form a foam, causing bubble burst-associated damage at the medium surface [120]. In most cases of mammalian cell culture, small bubbles (approximately $<2 \mathrm{~mm}$ in diameter) are more significantly damaging to cells than large bubbles $(10-20 \mathrm{~mm})$. Agitation by an impeller can also enhance cell membrane damage by disrupting the large gas bubbles arising from the sparger [121].

Stirred bioreactor also can be applied in PSC differentiation. Although one study demonstrated its capability to support the high-scale differentiation of PSCs such as cardiomyocytes from murine ESCs [122] and hepatocytes from hiPSCs [123], the hydrodynamic conditions in this bioreactor appear to produce a high subpopulation of cells with heterogeneous phenotypes of various types of cells [123, 124]. 


\subsubsection{Rotary Bottle Culture Systems}

Rotating bottle culture systems enhance the efficiency of aggregate formation, increase cell yield and homogeneity, and do not adversely affect differentiation [103]. This culture system was first developed by NASA to investigate cell culture systems in the space. Rotary culture systems consist of rotating $3 \mathrm{D}$ chambers to accommodate the cell culture, which is suspended under microgravity conditions, creating a continuous homogenous environment with low shear stress for PSCs culture (Fig. 1H). These hydrodynamic properties are very important for supporting the maintenance of aggregate formation in suspension culture. This system improves the homogeneous condition and prevents excess PSCsagglomeration $[103,125]$. In large-scale production of PSCs, their systems complexity causes difficulties in continuous feeding and uses a low working volume (approximately 10-500 mL) [112].

Several studies have demonstrated that the dynamic rotary suspension culture enhances PSCs aggregation and differentiation by supporting specific signaling pathways involved in directing cell fate. Lei et al. found that the biomechanical properties of this culture system induce Wnt/ $\beta$-catenin signaling, which is responsible for mouse ESC differentiation into the mesoderm and endoderm [126]. Another study revealed that the cardiogenic differentiation of murine ESC aggregates in a rotary culture environment can produce a higher percentage of contracting cardiomyocytes compared to differentiation in adherent culture [127].

\subsubsection{Hollow Fiber Bioreactor}

The hollow fiber bioreactor is a culture system based on a perfusion system that uses small semi-permeable membrane hollowed fiber tubes. By circulating the culture medium, this system can provide an exchange between small molecule components, such as nutrients and metabolic wastes (Fig. 1G). This system mimics the microenvironment of blood vessels in vivo by using two different compartments. The first compartment is an intercapillary space within the hollow fibers, while the second is extra-capillary space surrounding the hollow fibers [79]. The cells are cultured in the extra-capillary space, and oxygenated medium at an appropriate $\mathrm{pH}$ is circulated through hundreds to thousands of capillaries within the hollowfiber cartridge using perfusion systems. Oxygenation and $\mathrm{pH}$ control is achieved by a gas-permeable surface in a $\mathrm{CO}_{2}$ incubator. The exchange of nutrients and waste products is achieved by diffusion through the semi-permeable membrane fibers. A separate culture compartment and perfusion compartment produces the low-stress environment required for maintaining PSC pluripotency and viability. In this system, the culture compartment can be filled with up to $10^{8}$ cells $/ \mathrm{mL}$ (near the tissue density in vivo) [128]. Therefore, this system requires less medium and fewer growth factors than traditional culture methods. This high-density culture also can facilitate the threedimensional growth resembling the in vivo tissue structure to support PSC differentiation. Recent studies showed that the functional activity and formation of several tissue-like structures were increased in hepatocyte-derived hiPSC aggregates after hepatic differentiation using this system [129, 130].

However, hollow fiber systems have some disadvantages, such as difficulties in monitoring and controls. At high cell densities, spatial concentration gradients in the extra-capillary compartment can form, based on the distance of the PSCs to the intercapillary compartment. Previously, a study by Roberts et al. evaluated the potential and feasibility of using hollow fiber systems for hESC mass production. The results indicated that hESCs can be scaled up in a hollow fiber bioreactor without a significant decrease in pluripotency [131].

\section{OTHER IMPROVEMENTS TO ENHANCE PSC CULTURE SYSTEMS}

\subsection{Microcarriers}

In optimizing the scalable culture systems for expanding undifferentiated PSC culture, traditional adherent cell culture can be utilized on polymer- or hydrogel-based microcarrier beads [132]. Microcarriers can provide a high surface area for cell attachment and proliferation. This technique enables adherent-type cells to be treated as similar to the suspension culture. Compared to conventional static adherent culture, the main advantage of microcarriers is that they can accommodate a larger number of cells and occupy less space in the bioreactor [133]. According to a previous study, culturing on microcarriers was conducted using 2- to 4-fold higher densities of iPSCs than in conventional adherent culture [134].

Generally, microcarriers are divided into two types: nonporous microcarriers and porous microcarriers (Fig. 1B, 1C). Solid-filled microspheres or nonporous microcarriers are composed of bioceramic or biopolymers. Anchorage-dependent animal cells can be grown on the surface of small-diameter spheres that can be maintained similarly to in suspension cultures. Equal effects of nutrients and growth on the surface of microcarriers can be achieved to expand cells with homogeneous characteristics and differentiation. However, direct contact between the attached cell and media caused some frictional and shear stress, which can damage the cells, mainly when combined with highly hydrodynamic conditions such as in a stirred bioreactor. Porous microcarriers contain pores and channels that are large enough for cells to enter and grow within the carriers, which allow for culturing at higher cell densities than for nonporous microcarriers. In addition, these microcarriers can create a microenvironment inside the beads, protecting the cells from shear and frictional stresses caused by aeration and agitation in a dynamic bioreactor. Thus, porous microcarriers are more appropriate for large-scale mass production of cells compared to nonporous microcarriers. However, it is difficult to observe cells inside the microcarriers and separating and collecting the cells is challenging. In addition, the gradients of conditions, such as different in hydrodynamic properties, cell-cell interactions, and nutrition or oxygen concentrations, have been observed in pores. Consequently, nutrient transfer and cellular waste product release will be more limited for the cells inside the pores $[135,136]$. This condition also can cause variability among cultured PSCs undergoing expansion or differentiation.

Nonporous microcarriers can be coated with ECM such as collagen or fibronectin to enhance cell attachment and adhesion (Fig. 1D) [132, 137]. These coatings are completely dissolvable in trypsin solution, which allows the sampling, 
counting, and harvesting of the cells without interference from the carriers. Chen et al. investigated the cellular attachment efficiency, growth, and pluripotency of hESCs using 10 types of microcarriers. The study revealed that poor growth and gradual loss of pluripotency occurred at the same time because of a lack of ECM interactions in uncoated microcarriers. Higher yields and stable pluripotent states of hESCs grown using Matrigel-coated microcarriers were achieved compared to using other types of microcarrier culture [138]. A study also reported the successful differentiation of the mesoderm from hESCs and hESC using similar types of microcarriers [139].

Although cellulose is the most common material used for microcarriers, various other materials have also been used, such as hydroxyapatite, tricalcium phosphate, and glass ceramics. Synthetic degradable polymers such as polylactic acid, polyglycolic acid, and polycaprolactone are also used as microcarriers. According to a previous study, hESCs did not attach and grow on microcarriers with a negatively charged surface [65]. The sizes of the spheres are diverse depending on the conditions, such as material content, surfactant type and amount, type of solvent, and stirring speed. Synthetic polymers typically lack hydrophilic and adhesive ligands, which are required for cell attachment. Therefore, the surface requires hydrophilization and coating with adhesive proteins such as Matrigel, fibronectin, or collagen. For PSCs propagation, it has been reported that the use of combined materials in microcarriers can affect their cellular characteristics. For example, combining hydroxyapatite powder within polylactic acid can potentially improve cell adhesion, cell growth, and osteoblastic differentiation [135].

\subsection{Cell Encapsulation}

The main principle of cell encapsulation is to envelope viable cells or aggregates within semi-permeable membrane layers to protect the cells from shear stress and to accumulate the native products secreted from cells while exchanging nutrients and wastes (Fig. 1E) [140]. Various sizes of capsules are available for cell encapsulation, which are $0.3-1.5 \mathrm{~mm}$ or larger. Enclosing PSCsin hydrogel can create a microenvironment with cell-hydrogel contact and auto/paracrine effects while protecting them from the hydrodynamic shear stress. A report showed that encapsulation provided more than 6 months of prolonged feeder-free PSCs expansion in well maintained pluripotency [141]. Another report showed that the differentiation markers in encapsulated PSCs were downregulated compared to cells in conventional suspension culture, which prevented unexpected PSCs differentiation [142]. Besides for PSCs expansion, the cell encapsulation can also be utilized for differentiation. Kerscher et al. performed the cardiac differentiation of hiPSCs by using direct hydrogel encapsulation [143]. Various types of hydrogels are used for encapsulation, such as PEG [143], agarose [38], hyaluronic acid [144], and calcium alginate [145]. Calcium alginate hydrogel is the most widely used hydrogel for encapsulation because of its fast and reversible gelation. A recent investigation revealed that alginate composition can influence the cellular phenotype of murine ESCs towards the preservation of pluripotency or differentiation [146].
In contrast to these advantages, the application involves an encapsulation and decapsulation process, which is challenging when using hydrogel with non-reversible gelation. In addition, the PSCs which exhibit a high proliferation rate can escape from hydrogel capsules and break outside the capsules when it could not accommodate the cell growth. Coating capsules with a solid shell can prevent this escape but may increase the difficulties of decapsulation [145]. Thus, cell encapsulation can be utilized for long-term maintenance or implantation to achieve immuno-isolation by protecting cells from antibody recognition.

\subsection{Perfusion Systems}

To optimize the mass transfer of essential compounds, some bioreactors are equipped with continuous perfusion systems. This configuration provides better oxygen transport and enhance the cell feeding by frequently removing byproducts or metabolic wastes and replacing the fluids with fresh medium containing nutrients [98]. One study reported that PSCs cultivation successfully maintained with good viability, pluripotency, and genetic stability after 6 days of culture by automated perfusion feeding of mESCs in a Petri dish. This system also significantly enhanced the cellular growth rate [147].

\section{CONCLUSION AND FUTURE DIRECTIONS}

As described above, various bioreactor systems provide different microenvironments and physiological factors. In addition, the optimum condition for PSCs depends on the stage of culture, such as maintenance, propagation, or differentiation into target cells. For example, maintenance and propagation require rapid exchange of nutrients and wastes because of the rapids anaerobic respiration in these cells. Therefore, the perfusion system or fed-batch culture system is preferred for PSCs propagation. In contrast, the culture costs for differentiation are much higher than those during maintenance because it requires numerous amount of growth factors combinations. Therefore, the use of growth factors should be reduced, such as in dialysis culture systems. Thus, choosing an appropriate culture system is important for the industrial application of PSCs.

\section{CONSENT FOR PUBLICATION}

Not applicable.

\section{CONFLICT OF INTEREST}

The authors declare that there is no conflict of interest, financial or otherwise.

\section{ACKNOWLEDGEMENTS}

Declared none.

\section{REFERENCES}

[1] Y. Iwasaki, S. Sugita, M. Mandai, S. Yonemura, A. Onishi, S. Ito, M. Mochizuki, K. Ohno-Matsui, and M. Takahashi, "Differentiation/ purification protocol for retinal pigment epithelium from mouse induced pluripotent stem cells as a research tool", PLoS One, vol. 11, no. 7 , p. e0158282, 2016

[http://dx.doi.org/10.1371/journal.pone.0158282] [PMID: 27385038] 
[2] H. Kempf, B. Andree, and R. Zweigerdt, "Large-scale production of human pluripotent stem cell derived cardiomyocytes", Adv. Drug Deliv. Rev., vol. 96, pp. 18-30, 2016.

[http://dx.doi.org/10.1016/j.addr.2015.11.016] [PMID: 26658242]

[3] A. Rezania, J.E. Bruin, P. Arora, A. Rubin, I. Batushansky, A. Asadi, S. O'Dwyer, N. Quiskamp, M. Mojibian, T. Albrecht, Y.H. Yang, J.D. Johnson, and T.J. Kieffer, "Reversal of diabetes with insulin-producing cells derived in vitro from human pluripotent stem cells", Nat. Biotechnol., vol. 32, no. 11, pp. 1121-1133, 2014. [http://dx.doi.org/10.1038/nbt.3033] [PMID: 25211370]

[4] Y. Kondo, T. Iwao, K. Nakamura, T. Sasaki, S. Takahashi, N. Kamada, T. Matsubara, F.J. Gonzalez, H. Akutsu, Y. Miyagawa, H. Okita, N. Kiyokawa, M. Toyoda, A. Umezawa, K. Nagata, T. Matsunaga, and S. Ohmori, "An efficient method for differentiation of human induced pluripotent stem cells into hepatocyte-like cells retaining drug metabolizing activity", Drug Metab. Pharmacokinet., vol. 29 , no. 3, pp. $237-243,2014$

[http://dx.doi.org/10.2133/dmpk.DMPK-13-RG-104] [PMID: 2433 4537]

[5] M. Serra, and P.A. C. Brito, "Bioengineering strategies for stem cell expansion and differentiation", Rev da Soc Port Bioquímica., vol. 7, pp. 30-37, 2010.

[6] C.A.V. Rodrigues, T.G. Fernandes, M.M. Diogo, C.L. da Silva, and J.M.S. Cabral, "Stem cell cultivation in bioreactors", Biotechnol. Adv., vol. 29 , no. 6 , pp. $815-829,2011$

[http://dx.doi.org/10.1016/j.biotechadv.2011.06.009] [PMID: 21726 624]

[7] V.C. Chen, and L.A. Couture, "Development of scalable cGMPcompliant human embryonic stem cell suspension culture system", Isct., vol. 19, no. 5, pp. 1-6, 2012.

[8] Y. Lei, D. Jeong, J. Xiao, and D.V. Schaffer, "Developing defined and scalable 3D culture systems for culturing human pluripotent stem cells at high densities", Cell. Mol. Bioeng., vol. 7, no. 2, pp. 172-183, 2014. [http://dx.doi.org/10.1007/s12195-014-0333-z] [PMID: 25419247]

[9] J.A. Thomson, J. Itskovitz-Eldor, S.S. Shapiro, M.A. Waknitz, J.J. Swiergiel, V.S. Marshall, and J.M. Jones, "Embryonic stem cell lines derived from human blastocysts", Science, vol. 282, no. 5391, pp. 1145-1147, 1998.

[http://dx.doi.org/10.1126/science.282.5391.1145] [PMID: 9804556]

[10] A.D. Agulnick, D.M. Ambruzs, M.A. Moorman, A. Bhoumik, R.M. Cesario, J.K. Payne, J.R. Kelly, C. Haakmeester, R. Srijemac, A.Z. Wilson, J. Kerr, M.A. Frazier, E.J. Kroon, and K.A. D'Amour, "Insulin-Producing endocrine cells differentiated In Vitro from human embryonic stem cells function in macroencapsulation devices In Vivo", Stem Cells Transl. Med., vol. 4, no. 10, pp. 1214-1222, 2015. [http://dx.doi.org/10.5966/sctm.2015-0079] [PMID: 26304037]

[11] K. Takahashi, and S. Yamanaka, "Induction of pluripotent stem cells from mouse embryonic and adult fibroblast cultures by defined factors", Cell, vol. 126, no. 4, pp. 663-676, 2006. [http://dx.doi.org/10.1016/j.cell.2006.07.024] [PMID: 16904174]

[12] K. Takahashi, K. Tanabe, M. Ohnuki, M. Narita, T. Ichisaka, K. Tomoda, and S. Yamanaka, "Induction of pluripotent stem cells from adult human fibroblasts by defined factors", Cell, vol. 131, no. 5, pp. 861-872, 2007.

[http://dx.doi.org/10.1016/j.cell.2007.11.019] [PMID: 18035408]

[13] L.G. Villa-Diaz, A.M. Ross, J. Lahann, and P.H. Krebsbach, "Concise review: The evolution of human pluripotent stem cell culture: from feeder cells to synthetic coatings", Stem Cells, vol. 31, no. 1, pp. 1-7, 2013.

[http://dx.doi.org/10.1002/stem.1260] [PMID: 23081828]

[14] S.Y. Wong, J. Soto, and S. Li, "Biophysical regulation of cell reprogramming", Curr. Opin. Chem. Eng., vol. 15, pp. 95-101, 2017. [http://dx.doi.org/10.1016/j.coche.2017.01.001] [PMID: 28413770]

[15] T.C. McDevitt, and S.P. Palecek, "Innovation in the culture and derivation of pluripotent human stem cells", Curr. Opin. Biotechnol., vol. 19 , no. 5 , pp. $527-533,2008$

[http://dx.doi.org/10.1016/j.copbio.2008.08.005] [PMID: 18760357]

[16] M. Serra, C. Brito, M.F.Q. Sousa, J. Jensen, R. Tostões, J. Clemente, R. Strehl, J. Hyllner, M.J. Carrondo, and P.M. Alves, "Improving expansion of pluripotent human embryonic stem cells in perfused bioreactors through oxygen control", J. Biotechnol., vol. 148, no. 4, pp. 208-215, 2010 .

[http://dx.doi.org/10.1016/j.jbiotec.2010.06.015] [PMID: 20600380]

[17] K. Okita, and S. Yamanaka, "Induced pluripotent stem cells: opportunities and challenges", Philos. Trans. R. Soc. Lond. B Biol. Sci., vol. 366, no. 1575 , pp. 2198-2207, 2011.

[http://dx.doi.org/10.1098/rstb.2011.0016] [PMID: 21727125]
[18] K Okita, M Nakagawa, H Hyenjong, T Ichisaka, and S Yamanaka, "Generation of mouse induced pluripotent stem cells without viral vectors", Science (80-), vol. 322, no. 5903, pp. 949-53, 2008. [http://dx.doi.org/10.1126/science.1164270]

[19] T. Ma, M. Xie, T. Laurent, and S. Ding, "Progress in the reprogramming of somatic cells", Circ. Res., vol. 112, no. 3, pp. 562-574, 2013.

[http://dx.doi.org/10.1161/CIRCRESAHA.111.249235] [PMID: 2337 1904]

[20] J.H. Hanna, K. Saha, and R. Jaenisch, "Pluripotency and cellular reprogramming: facts, hypotheses, unresolved issues", Cell, vol. 143, no. 4 , pp. $508-525,2010$

[http://dx.doi.org/10.1016/j.cell.2010.10.008] [PMID: 21074044]

[21] M. Brouwer, H. Zhou, and N. Nadif Kasri, "Choices for induction of pluripotency: Recent developments in human induced pluripotent stem cell reprogramming strategies", Stem Cell Rev., vol. 12, no. 1, pp. 54-72, 2016.

[http://dx.doi.org/10.1007/s12015-015-9622-8] [PMID: 26424535]

[22] T Eguchi, and T. Kuboki, "Cellular reprogramming using defined factors and microRNAs", Stem Cells Int, vol. 2016, 2016.

[http://dx.doi.org/10.1155/2016/7530942]

[23] X-Y. Deng, H. Wang, T. Wang, X-T. Fang, L-L. Zou, Z-Y. Li, and CB. Liu, "Non-viral methods for generating integration-free, induced pluripotent stem cells", Curr. Stem Cell Res. Ther., vol. 10, no. 2, pp. 153-158, 2015.

[http://dx.doi.org/10.2174/1574888X09666140923101914] [PMID: 25248676]

[24] T.M. Schlaeger, L. Daheron, T.R. Brickler, S. Entwisle, K. Chan, A Cianci, A. DeVine, A. Ettenger, K. Fitzgerald, M. Godfrey, D. Gupta, J. McPherson, P. Malwadkar, M. Gupta, B. Bell, A. Doi, N. Jung, X. Li, M.S. Lynes, E. Brookes, A.B. Cherry, D. Demirbas, A.M. Tsankov, L.I. Zon, L.L. Rubin, A.P. Feinberg, A. Meissner, C.A. Cowan, and G.Q. Daley, "A comparison of non-integrating reprogramming methods", Nat. Biotechnol., vol. 33, no. 1, pp. 58-63, 2015. [http://dx.doi.org/10.1038/nbt.3070] [PMID: 25437882]

[25] Y.Y. Zhou, and F. Zeng, "Integration-free methods for generating induced pluripotent stem cells", Genomics Proteomics Bioinf, vol. 11, no. 5 , pp. $284-287,2013$.

[http://dx.doi.org/10.1016/j.gpb.2013.09.008] [PMID: 24121200]

[26] A.D. Bangham, R.W. Horne, A.M. Glauert, J.T. Dingle, and J.A. Lucy, "Action of saponin on biological cell membranes", Nature, vol. 196, pp. 952-955, 1962.

[http://dx.doi.org/10.1038/196952a0] [PMID: 13966357]

[27] W. Li, Y. Han, H. Yang, G. Wang, R. Lan, and J.Y. Wang, "Preparation of microcarriers based on zein and their application in cell culture", Mater. Sci. Eng. C, vol. 58, pp. 863-869, 2016.

[http://dx.doi.org/10.1016/j.msec.2015.09.045] [PMID: 26478381]

[28] D. Wang, W. Liu, B. Han, and R. Xu, "The bioreactor: a powerful tool for large-scale culture of animal cells", Curr. Pharm. Biotechnol., vol. 6, no. 5, pp. 397-403, 2005. [http://dx.doi.org/10.2174/138920105774370580] [PMID: 16248813]

[29] R. Zweigerdt, "Large scale production of stem cells and their derivatives", Adv. Biochem. Eng. Biotechnol., vol. 2009, no. 123, pp. 127-141, 2015. [PMID: 19513633]

[30] E. Bianconi, A. Piovesan, F. Facchin, A. Beraudi, R. Casadei, F. Frabetti, L. Vitale, M.C. Pelleri, S. Tassani, F. Piva, S. Perez-Amodio, P. Strippoli, and S. Canaider, "An estimation of the number of cells in the human body", Ann. Hum. Biol., vol. 40, no. 6, pp. 463-471, 2013. [http://dx.doi.org/10.3109/03014460.2013.807878] [PMID: 23829164]

[31] N. Lavon, M. Zimerman, and J. Itskovitz-Eldor, "Scalable expansion of pluripotent stem cells", Adv. Biochem. Eng. Biotechnol., vol. 163, pp. 23-37, 2018.

[http://dx.doi.org/10.1007/10_2017_26] [PMID: 29085956]

[32] S.M. Frisch, and R.A. Screaton, "Anoikis mechanisms", Curr. Opin. Cell Biol., vol. 13, no. 5, pp. 555-562, 2001.

[http://dx.doi.org/10.1016/S0955-0674(00)00251-9] [PMID: 11544 023]

[33] G. Chen, Z. Hou, D. Gulbranson, and J.A. Thomson, "Actin-myosin contractility is responsible for the reduced viability of dissociated human embryonic stem cells", Cell Stem Cell, vol. 313, no. 1, pp. 178-191, 2012.

[PMID: 20682449]

[34] M. Ohgushi, and Y. Sasai, "Lonely death dance of human pluripotent stem cells: ROCKing between metastable cell states", Trends Cell Biol., vol. 21, no. 5, pp. 274-282, 2011 [http://dx.doi.org/10.1016/j.tcb.2011.02.004] [PMID: 21444207] 
[35] J.K. Earls, S. Jin, and K. Ye, "Mechanobiology of human pluripotent stem cells", Tissue Eng. Part B Rev., vol. 19, no. 5, pp. 420-430, 2013. [http://dx.doi.org/10.1089/ten.teb.2012.0641] [PMID: 23472616]

[36] K. Watanabe, M. Ueno, D. Kamiya, A. Nishiyama, M. Matsumura, T. Wataya, J.B. Takahashi, S. Nishikawa, S. Nishikawa, K. Muguruma, and Y. Sasai, "A ROCK inhibitor permits survival of dissociated human embryonic stem cells", Nat. Biotechnol., vol. 25, no. 6, pp. 681-686, 2007.

[http://dx.doi.org/10.1038/nbt1310] [PMID: 17529971]

[37] Y. Xu, X. Zhu, H.S. Hahm, W. Wei, E. Hao, A. Hayek, and S. Ding, "Revealing a core signaling regulatory mechanism for pluripotent stem cell survival and self-renewal by small molecules", Proc. Natl. Acad. Sci. USA, vol. 107, no. 18, pp. 8129-8134, 2010. [http://dx.doi.org/10.1073/pnas.1002024107] [PMID: 20406903]

[38] F. Ulloa-Montoya, C.M. Verfaillie, and W-S. Hu, "Culture systems for pluripotent stem cells", J. Biosci. Bioeng., vol. 100, no. 1, pp. 12-27, 2005.

[http://dx.doi.org/10.1263/jbb.100.12] [PMID: 16233846]

[39] D. James, A.J. Levine, D. Besser, and A. Hemmati-Brivanlou, "TGFbeta/activin/nodal signaling is necessary for the maintenance of pluripotency in human embryonic stem cells", Development, vol. 132, no. 6 , pp. 1273-1282, 2005.

[http://dx.doi.org/10.1242/dev.01706] [PMID: 15703277]

[40] T. Watabe, and K. Miyazono, "Roles of TGF- $\beta$ family signaling in stem cell renewal and differentiation", Cell Res., vol. 19, no. 1, pp. 103-115, 2009.

[http://dx.doi.org/10.1038/cr.2008.323] [PMID: 19114993]

[41] DA Turner, J Trott, P Hayward, and P Rue, "An interplay between extracellular signalling and the dynamics of the exit from pluripotency drives cell fate decisions in mouse ES cells", [http://dx.doi.org/10.1242/bio.20148409]

[42] L. Vallier, S. Mendjan, S. Brown, Z. Chng, A. Teo, L.E. Smithers, M.W.B. Trotter, C.H-H. Cho, A. Martinez, P. Rugg-Gunn, G. Brons, and R.A. Pedersen, "Activin/Nodal signalling maintains pluripotency by controlling Nanog expression", Development, vol. 136, no. 8, pp. 1339-1349, 2009.

[http://dx.doi.org/10.1242/dev.033951] [PMID: 19279133]

[43] D. Cheng, Y. Guo, Z. Li, Y. Liu, X. Gao, Y. Gao, X. Cheng, J. Hu, and H. Wang, "Porcine induced pluripotent stem cells require LIF and maintain their developmental potential in early stage of embryos", PLoS One, vol. 7, no. 12, p. e51778, 2012.

[http://dx.doi.org/10.1371/journal.pone.0051778] [PMID: 23251622]

[44] M. Morikawa, D. Koinuma, A. Mizutani, N. Kawasaki, K. Holmborn, A. Sundqvist, S. Tsutsumi, T. Watabe, H. Aburatani, C.H. Heldin, and K. Miyazono, "BMP sustains embryonic stem cell self-renewal through distinct functions of different Krüppel-like factors", Stem Cell Reports, vol. 6, no. 1, pp. 64-73, 2016.

[http://dx.doi.org/10.1016/j.stemcr.2015.12.004] [PMID: 26771354]

[45] I. Horiguchi, Y. Urabe, K. Kimura, and Y. Sakai, "Effects of glucose, lactate and basic FGF as limiting factors on the expansion of human induced pluripotent stem cells", J. Biosci. Bioeng., vol. 125, no. 1, pp. 111-115, 2018.

[http://dx.doi.org/10.1016/j.jbiosc.2017.08.004] [PMID: 28864123]

[46] C. Mulas, T. Kalkan, and A. Smith, "NODAL secures pluripotency upon embryonic stem cell progression from the ground state", Stem Cell Reports, vol. 9, no. 1, pp. 77-91, 2017.

[http://dx.doi.org/10.1016/j.stemcr.2017.05.033] [PMID: 28669603]

[47] S. Llames, E. García-Pérez, Á. Meana, F. Larcher, and M. del Río, "Feeder layer cell actions and applications", Tissue Eng. Part B Rev., vol. 21 , no. 4 , pp. $345-353,2015$

[http://dx.doi.org/10.1089/ten.teb.2014.0547] [PMID: 25659081]

[48] M. Tewary, N. Shakiba, and P.W. Zandstra, "Stem cell bioengineering: building from stem cell biology", Nat. Rev. Genet., vol. 19, no. 10, pp. 595-614, 2018.

[http://dx.doi.org/10.1038/s41576-018-0040-z] [PMID: 30089805]

[49] L Eiselleova, I Peterkova, J Neradil, IVA Slaninova, A Hampl, and P Dvorak, "Comparative study of mouse and human feeder cells for human embryonic stem cells",

[http://dx.doi.org/10.1387/ijdb.082590le]

[50] R Xu, RM Peck, DS Li, X Feng, T Ludwig, and JA Thomson, "Basic FGF and suppression of BMP signaling sustain undifferentiated proliferation of human ES cells",

[http://dx.doi.org/10.1038/nmeth744]

[51] B.J. Cowling, G. Freeman, J.Y. Wong, P. Wu, Q. Liao, E.H. Lau, J.T. Wu, R. Fielding, and G.M. Leung, "Preliminary inferences on the agespecific seriousness of human disease caused by avian influenza A(H7N9) infections in China, March to April 2013", Euro Surveill., vol. 18 , no. 19 , p. 20475,2013 [PMID: 23725807]

[52] S. Abraham, S.D. Sheridan, B. Miller, and R.R. Rao, "Stable propagation of human embryonic and induced pluripotent stem cells on decellularized human substrates", Biotechnol. Prog., vol. 26, no. 4, pp. 1126-1134, 2010. [PMID: 20730767]

[53] M.J. Martin, A. Muotri, F. Gage, and A. Varki, "Human embryonic stem cells express an immunogenic nonhuman sialic acid", Nat. Med., vol. 11 , no. 2 , pp. 228-232, 2005.

[http://dx.doi.org/10.1038/nm1181] [PMID: 15685172]

[54] C.M. Madl, S.C. Heilshorn, and H.M. Blau, "Bioengineering strategies to accelerate stem cell therapeutics", Nature, vol. 557, no. 7705, pp. 335-342, 2018.

[http://dx.doi.org/10.1038/s41586-018-0089-z] [PMID: 29769665]

[55] C. Unger, S. Gao, M. Cohen, M. Jaconi, R. Bergstrom, F. Holm, A. Galan, E. Sanchez, O. Irion, J.B. Dubuisson, M. Giry-Laterriere, P. Salmon, C. Simon, O. Hovatta, and A. Feki, "Immortalized human skin fibroblast feeder cells support growth and maintenance of both human embryonic and induced pluripotent stem cells", Hum. Reprod., vol. 24 , no. 10, pp. 2567-2581, 2009.

[http://dx.doi.org/10.1093/humrep/dep232] [PMID: 19556288]

[56] M Pekkanen-Mattila, M Ojala, E Kerkelä, K Rajala, H Skottman, and K Aalto-Setälä, "The effect of human and mouse fibroblast feeder cells on cardiac differentiation of human pluripotent stem cells", Stem Cells Int, vol. 2012, 2012.

[http://dx.doi.org/10.1155/2012/875059]

[57] S. Sugii, Y. Kida, W.T. Berggren, R.M. Evans, W. Li, S. Hilcove, X Lin, H.S. Hahm, E. Hao, and A. Hayek, "Feeder-dependent and feederindependent iPS cell derivation from human and mouse adipose stem cells", Nat. Protoc., vol. 6, no. 3, pp. 346-358, 2011.

[http://dx.doi.org/10.1038/nprot.2010.199] [PMID: 21372815]

[58] S.T. Hwang, S.W. Kang, S.J. Lee, T.H. Lee, W. Suh, S.H. Shim, D.R. Lee, L.J. Taite, K.S. Kim, and S.H. Lee, "The expansion of human ES and iPS cells on porous membranes and proliferating human adiposederived feeder cells", Biomaterials, vol. 31, no. 31, pp. 8012-8021, 2010 .

[http://dx.doi.org/10.1016/j.biomaterials.2010.07.031] [PMID: 2067 4000]

[59] Q. Chen, C. Qiu, Y. Huang, L. Jiang, Q. Huang, L. Guo, and T. Liu, "Human amniotic epithelial cell feeder layers maintain iPS cell pluripotency by inhibiting endogenous DNA methyltransferase 1", Exp. Ther. Med., vol. 6, no. 5, pp. 1145-1154, 2013.

[http://dx.doi.org/10.3892/etm.2013.1279] [PMID: 24223636]

[60] T. Liu, Q. Chen, Y. Huang, Q. Huang, L. Jiang, and L. Guo, "Low microRNA-199a expression in human amniotic epithelial cell feeder layers maintains human-induced pluripotent stem cell pluripotency via increased leukemia inhibitory factor expression", Acta Biochim. Biophys. Sin. (Shanghai), vol. 44, no. 3, pp. 197-206, 2012. [http://dx.doi.org/10.1093/abbs/gmr127] [PMID: 22285730]

[61] M. Richards, S. Tan, C-Y. Fong, A. Biswas, W-K. Chan, and A. Bongso, "Comparative evaluation of various human feeders for prolonged undifferentiated growth of human embryonic stem cells", Stem Cells, vol. 21, no. 5, pp. 546-556, 2003.

[http://dx.doi.org/10.1634/stemcells.21-5-546] [PMID: 12968109]

[62] M. Richards, C-Y. Fong, W-K. Chan, P-C. Wong, and A. Bongso, "Human feeders support prolonged undifferentiated growth of human inner cell masses and embryonic stem cells", Nat. Biotechnol., vol. 20, no. 9, pp. 933-936, 2002.

[http://dx.doi.org/10.1038/nbt726] [PMID: 12161760]

[63] K. Zhang, Z. Cai, Y. Li, J. Shu, L. Pan, F. Wan, H. Li, X. Huang, C. He, Y. Liu, X. Cui, Y. Xu, Y. Gao, L. Wu, S. Cao, and L. Li, "Utilization of human amniotic mesenchymal cells as feeder layers to sustain propagation of human embryonic stem cells in the undifferentiated state", Cell. Reprogram., vol. 13, no. 4, pp. 281-288, 2011. [http://dx.doi.org/10.1089/cell.2010.0103] [PMID: 21718108]

[64] K. Takahashi, M. Narita, M. Yokura, T. Ichisaka, and S. Yamanaka, "Human induced pluripotent stem cells on autologous feeders", PLoS One, vol. 4, no. 12, p. e8067, 2009.

[http://dx.doi.org/10.1371/journal.pone.0008067] [PMID: 19956543]

[65] B.S. Mallon, K-Y. Park, K.G. Chen, R.S. Hamilton, and R.D.G. McKay, "Toward xeno-free culture of human embryonic stem cells", Int. J. Biochem. Cell Biol., vol. 38, no. 7, pp. 1063-1075, 2006 [http://dx.doi.org/10.1016/j.biocel.2005.12.014] [PMID: 16469522]

[66] S. Yamasaki, Y. Taguchi, A. Shimamoto, H. Mukasa, H. Tahara, and T. Okamoto, "Generation of human induced pluripotent stem (Ips) cells in serum- and feeder-free defined culture and TGF-B1 regulation 
of pluripotency", PLoS One, vol. 9, no. 1, p. e87151, 2014. [http://dx.doi.org/10.1371/journal.pone.0087151] [PMID: 24489856]

[67] S. Rodin, A. Domogatskaya, S. Ström, E.M. Hansson, K.R. Chien, J. Inzunza, O. Hovatta, and K. Tryggvason, "Long-term self-renewal of human pluripotent stem cells on human recombinant laminin-511", Nat. Biotechnol., vol. 28, no. 6, pp. 611-615, 2010.

[http://dx.doi.org/10.1038/nbt.1620] [PMID: 20512123]

[68] S. Rodin, L. Antonsson, O. Hovatta, and K. Tryggvason, "Monolayer culturing and cloning of human pluripotent stem cells on laminin-521based matrices under xeno-free and chemically defined conditions", Nat. Protoc., vol. 9, no. 10, pp. 2354-2368, 2014.

[http://dx.doi.org/10.1038/nprot.2014.159] [PMID: 25211513]

[69] M. Nakagawa, Y. Taniguchi, S. Senda, N. Takizawa, T. Ichisaka, K. Asano, A. Morizane, D. Doi, J. Takahashi, M. Nishizawa, Y. Yoshida, T. Toyoda, K. Osafune, K. Sekiguchi, and S. Yamanaka, "A novel efficient feeder-free culture system for the derivation of human induced pluripotent stem cells", Sci. Rep., vol. 4, p. 3594, 2014. [http://dx.doi.org/10.1038/srep03594] [PMID: 24399248]

[70] G. Chen, D.R. Gulbranson, Z. Hou, J.M. Bolin, V. Ruotti, M.D. Probasco, K. Smuga-Otto, S.E. Howden, N.R. Diol, N.E. Propson, R. Wagner, G.O. Lee, J. Antosiewicz-Bourget, J.M. Teng, and J.A. Thomson, "Chemically defined conditions for human iPSC derivation and culture", Nat. Methods, vol. 8, no. 5, pp. 424-429, 2011. [http://dx.doi.org/10.1038/nmeth.1593] [PMID: 21478862]

[71] V.C. Chen, S.M. Couture, J. Ye, Z. Lin, G. Hua, H.I.P. Huang, J. Wu, D. Hsu, M.K. Carpenter, and L.A. Couture, "Scalable GMP compliant suspension culture system for human ES cells", Stem Cell Res. (Amst.), vol. 8 , no. 3, pp. 388-402, 2012.

[http://dx.doi.org/10.1016/j.scr.2012.02.001] [PMID: 22459095]

[72] H. Singh, P. Mok, T. Balakrishnan, S.N.B. Rahmat, and R. Zweigerdt, "Up-scaling single cell-inoculated suspension culture of human embryonic stem cells", Stem Cell Res. (Amst.), vol. 4, no. 3, pp. 165-179, 2010.

[http://dx.doi.org/10.1016/j.scr.2010.03.001] [PMID: 20363202]

[73] Y. Fan, J. Wu, P. Ashok, M. Hsiung, and E.S. Tzanakakis, "Production of human pluripotent stem cell therapeutics under defined xeno-free conditions: progress and challenges", Stem Cell Rev., vol. 11, no. 1, pp. 96-109, 2015.

[http://dx.doi.org/10.1007/s12015-014-9544-x] [PMID: 25077810]

[74] D.A. Fluri, P.D. Tonge, H. Song, R.P. Baptista, N. Shakiba, S. Shukla, G. Clarke, A. Nagy, and P.W. Zandstra, "Derivation, expansion and differentiation of induced pluripotent stem cells in continuous suspension cultures", Nat. Methods, vol. 9, no. 5, pp. 509-516, 2012. [http://dx.doi.org/10.1038/nmeth.1939] [PMID: 22447133]

[75] D. Zujur, K. Kanke, A.C. Lichtler, H. Hojo, U.I. Chung, and S. Ohba, "Three-dimensional system enabling the maintenance and directed differentiation of pluripotent stem cells under defined conditions", Sci. $A d v$., vol. 3, no. 5, p. e1602875, 2017

[http://dx.doi.org/10.1126/sciadv.1602875] [PMID: 28508073]

[76] Y. Kato, M.H. Kim, and M. Kino-Oka, "Comparison of growth kinetics between static and dynamic cultures of human induced pluripotent stem cells", J. Biosci. Bioeng., vol. 125, no. 6, pp. 736-740, 2018.

[http://dx.doi.org/10.1016/j.jbiosc.2018.01.002] [PMID: 29398548]

[77] H. Lin, Q. Li, and Y. Lei, "Three-dimensional tissues using human pluripotent stem cell spheroids as biofabrication building blocks", Biofabrication, vol. 9, no. 2, p. 025007, 2017.

[http://dx.doi.org/10.1088/1758-5090/aa663b] [PMID: 28287080]

[78] V. Barron, E. Lyons, C. Stenson-Cox, P.E. McHugh, and A. Pandit, "Bioreactors for cardiovascular cell and tissue growth: a review", Ann. Biomed. Eng., vol. 31, no. 9, pp. 1017-1030, 2003.

[http://dx.doi.org/10.1114/1.1603260] [PMID: 14582605]

[79] Y. Martin, and P. Vermette, "Bioreactors for tissue mass culture: design, characterization, and recent advances", Biomaterials, vol. 26, no. 35 , pp. 7481-7503, 2005.

[http://dx.doi.org/10.1016/j.biomaterials.2005.05.057] [PMID: 1602 3202]

[80] F.S. Veraitch, R. Scott, J.W. Wong, G.J. Lye, and C. Mason, "The impact of manual processing on the expansion and directed differentiation of embryonic stem cells", Biotechnol. Bioeng., vol. 99, no. 5, pp. 1216-1229, 2008. [http://dx.doi.org/10.1002/bit.21673] [PMID: 17929326]

[81] J.T. Cormier, N.I. zur Nieden, D.E. Rancourt, and M.S. Kallos, "Expansion of undifferentiated murine embryonic stem cells as aggregates in suspension culture bioreactors", Tissue Eng., vol. 12, no. 11 , pp. 3233-3245, 2006

[http://dx.doi.org/10.1089/ten.2006.12.3233] [PMID: 17518637]
[82] A. Wilmes, C. Rauch, G. Carta, G. Kern, F. Meier, W. Posch, D. Wilflingseder, L. Armstrong, M. Lako, M. Beilmann, G. Gstraunthaler, and P. Jennings, "Towards optimisation of induced pluripotent cell culture: Extracellular acidification results in growth arrest of iPSC prior to nutrient exhaustion", Toxicol. In Vitro, vol. 45, no. Pt 3, pp. 445-454, 2017. [http://dx.doi.org/10.1016/j.tiv.2017.07.023] [PMID: 28821352]

[83] P. Gupta, K. Hourigan, S. Jadhav, J. Bellare, and P. Verma, "Effect of lactate and $\mathrm{pH}$ on mouse pluripotent stem cells: Importance of media analysis", Biochem. Eng. J., vol. 118, pp. 25-33, 2017. [http://dx.doi.org/10.1016/j.bej.2016.11.005]

[84] J.G. Lees, D.K. Gardner, and A.J. Harvey, "Pluripotent stem cell metabolism and mitochondria: Beyond ATP", Stem Cells Int., vol. 2017, p. 2874283, 2017.

[http://dx.doi.org/10.1155/2017/2874283] [PMID: 28804500]

[85] T.G. Otsuji, J. Bin, A. Yoshimura, M. Tomura, D. Tateyama, I. Minami, Y. Yoshikawa, K. Aiba, J.E. Heuser, T. Nishino, K. Hasegawa, and N. Nakatsuji, "A 3D sphere culture system containing functional polymers for large-scale human pluripotent stem cell production", Stem Cell Reports, vol. 2, no. 5, pp. 734-745, 2014. [http://dx.doi.org/10.1016/j.stemcr.2014.03.012] [PMID: 24936458]

[86] W.L. Grayson, F. Zhao, B. Bunnell, and T. Ma, "Hypoxia enhances proliferation and tissue formation of human mesenchymal stem cells", Biochem. Biophys. Res. Commun., vol. 358, no. 3, pp. 948-953, 2007. [http://dx.doi.org/10.1016/j.bbrc.2007.05.054] [PMID: 17521616]

[87] T. Ezashi, P. Das, and R.M. Roberts, "Low O2 tensions and the prevention of differentiation of hES cells", Proc. Natl. Acad. Sci. USA, vol. 102 , no. 13 , pp. $4783-4788,2005$.

[http://dx.doi.org/10.1073/pnas.0501283102] [PMID: 15772165]

[88] Y. Yoshida, K. Takahashi, K. Okita, T. Ichisaka, and S. Yamanaka, "Hypoxia enhances the generation of induced pluripotent stem cells", Cell Stem Cell, vol. 5, no. 3, pp. 237-241, 2009.

[http://dx.doi.org/10.1016/j.stem.2009.08.001] [PMID: 19716359]

[89] L.B. Hazeltine, J.A. Selekman, and S.P. Palecek, "Engineering the human pluripotent stem cell microenvironment to direct cell fate", Biotechnol. Adv., vol. 31, no. 7, pp. 1002-1019, 2013.

[http://dx.doi.org/10.1016/j.biotechadv.2013.03.002] [PMID: 23510 904]

[90] X. Soriano Felipe, A. Guerrero Espejo, and S. Bonanad Boix, "Cloning and stem cells", Med. Clin. Barc., vol. 122, no. 4, pp. 150-154, 2004 [http://dx.doi.org/10.1016/S0025-7753(04)74176-7] [PMID: 14967 099]

[91] K. Si-Tayeb, F.K. Noto, M. Nagaoka, J. Li, M.A. Battle, C. Duris, P.E. North, S. Dalton, and S.A. Duncan, "Highly efficient generation of human hepatocyte-like cells from induced pluripotent stem cells", Hepatology, vol. 51, no. 1, pp. 297-305, 2010. [http://dx.doi.org/10.1002/hep.23354] [PMID: 19998274]

[92] C.L. Bauwens, R. Peerani, S. Niebruegge, K.A. Woodhouse, E Kumacheva, M. Husain, and P.W. Zandstra, "Control of human embryonic stem cell colony and aggregate size heterogeneity influences differentiation trajectories", Stem Cells, vol. 26, no. 9, pp. 2300-2310, 2008

[http://dx.doi.org/10.1634/stemcells.2008-0183] [PMID: 18583540]

[93] T. Toyoda, S. Mae, H. Tanaka, Y. Kondo, M. Funato, Y. Hosokawa, T. Sudo, Y. Kawaguchi, and K. Osafune, "Cell aggregation optimizes the differentiation of human ESCs and iPSCs into pancreatic bud-like progenitor cells", Stem Cell Res. Amst., vol. 14, no. 2, pp. 185-197, 2015 .

[http://dx.doi.org/10.1016/j.scr.2015.01.007] [PMID: 25665923]

[94] T. Hamazaki, M. Oka, S. Yamanaka, and N. Terada, "Aggregation of embryonic stem cells induces Nanog repression and primitive endoderm differentiation", J. Cell Sci., vol. 117, no. Pt 23, pp. 5681-5686, 2004

[http://dx.doi.org/10.1242/jcs.01489] [PMID: 15494369]

[95] S.C. Nath, M. Horie, E. Nagamori, and M. Kino-Oka, "Size- and timedependent growth properties of human induced pluripotent stem cells in the culture of single aggregate", J. Biosci. Bioeng., vol. 124, no. 4, pp. 469-475, 2017.

[http://dx.doi.org/10.1016/j.jbiosc.2017.05.006] [PMID: 28601606]

[96] E. Sachlos, and D.T. Auguste, "Embryoid body morphology influences diffusive transport of inductive biochemicals: a strategy for stem cell differentiation", Biomaterials, vol. 29, no. 34, pp. 4471-4480, 2008. [http://dx.doi.org/10.1016/j.biomaterials.2008.08.012] [PMID: 1879 3799]

[97] R. Olmer, A. Lange, S. Selzer, C. Kasper, A. Haverich, U. Martin, and R. Zweigerdt, "Suspension culture of human pluripotent stem cells in 
controlled, stirred bioreactors", Tissue Eng. Part C Methods, vol. 18, no. 10 , pp. $772-784,2012$

[http://dx.doi.org/10.1089/ten.tec.2011.0717] [PMID: 22519745]

[98] J.A. King, and W.M. Miller, "Bioreactor development for stem cell expansion and controlled differentiation", Curr. Opin. Chem. Biol., vol. 11 , no. 4 , pp. 394-398, 2007.

[http://dx.doi.org/10.1016/j.cbpa.2007.05.034] [PMID: 17656148]

[99] I Horiguchi, and Y. Sakai, "Serum replacement with albuminassociated lipids prevents excess aggregation and enhances growth of induced pluripotent stem cells in suspension culture",

[http://dx.doi.org/10.1002/btpr.2301]

[100] K.M. Fridley, M.A. Kinney, and T.C. McDevitt, "Hydrodynamic modulation of pluripotent stem cells", Stem Cell Res. Ther., vol. 3, no. 6, p. 45, 2012.

[http://dx.doi.org/10.1186/scrt136] [PMID: 23168068]

[101] K.H. Vining, and D.J. Mooney, "Mechanical forces direct stem cell behaviour in development and regeneration", Nat. Rev. Mol. Cell Biol., vol. 18 , no. 12 , pp. $728-742,2017$.

[http://dx.doi.org/10.1038/nrm.2017.108] [PMID: 29115301]

[102] D.E. Kehoe, D. Jing, L.T. Lock, E.S. Tzanakakis, and D. Ph, "Scalable stirred-suspension bioreactor culture of human pluripotent stem cells", Tissue Eng. Part A, vol. 16, no. 2, pp. 405-421, 2010. [http://dx.doi.org/10.1089/ten.tea.2009.0454] [PMID: 19739936]

[103] C.Y. Sargent, G.Y. Berguig, M.A. Kinney, L.A. Hiatt, R.L. Carpenedo, R.E. Berson, and T.C. McDevitt, "Hydrodynamic modulation of embryonic stem cell differentiation by rotary orbital suspension culture", Biotechnol. Bioeng., vol. 105, no. 3, pp. 611-626, 2010.

[http://dx.doi.org/10.1002/bit.22578] [PMID: 19816980]

[104] H-J. Henzler, "Particle stress in bioreactors", Adv. Biochem. Eng. Biotechnol., vol. 67, pp. 35-82, 2000.

[http://dx.doi.org/10.1007/3-540-47865-5_2] [PMID: 10857221]

[105] F.F. dos Santos, P.Z. Andrade, C.L. da Silva, and J.M.S. Cabral, "Bioreactor design for clinical-grade expansion of stem cells", Biotechnol. J., vol. 8, no. 6, pp. 644-654, 2013.

[http://dx.doi.org/10.1002/biot.201200373] [PMID: 23625834]

[106] PRT Archibald, A Chandra, D Thomas, and O Chose, "Comparability of automated human induced pluripotent stem cell culture : a pilot study",

[http://dx.doi.org/10.1007/s00449-016-1659-9]

[107] T. Kikuchi, M. Kino-Oka, M. Wada, T. Kobayashi, M. Kato, S. Takeda, H. Kubo, T. Ogawa, H. Sunayama, K. Tanimoto, M. Mizutani, T. Shimizu, and T. Okano, "A novel, flexible and automated manufacturing facility for cell-based health care products: Tissue Factory", Regen Ther, vol. 9, pp. 89-99, 2018.

[http://dx.doi.org/10.1016/j.reth.2018.08.004] [PMID: 30525079]

[108] M. Daniszewski, D.E. Crombie, R. Henderson, H.H. Liang, R.C.B. Wong, A.W. Hewitt, and A. Pébay, "Automated Cell Culture Systems and Their Applications to Human Pluripotent Stem Cell Studies", SLAS Technol., vol. 23, no. 4, pp. 315-325, 2018. [http://dx.doi.org/10.1177/2472630317712220] [PMID: 28574793]

[109] R.A. Felder, and D. Ph, A Review of Cell Culture Automation., JALA, 2002.

[110] F.A.C. Soares, A. Chandra, R.J. Thomas, R.A. Pedersen, L. Vallier, and D.J. Williams, "Investigating the feasibility of scale up and automation of human induced pluripotent stem cells cultured in aggregates in feeder free conditions", J. Biotechnol., vol. 173, no. 1, pp. 53-58, 2014.

[http://dx.doi.org/10.1016/j.jbiotec.2013.12.009] [PMID: 24440272]

[111] S. Haupt, J. Grützner, M.C. Thier, T. Kallweit, B.H. Rath, I. Laufenberg, M. Forgber, J. Eberhardt, F. Edenhofer, and O. Brüstle, "Automated selection and harvesting of pluripotent stem cell colonies", Biotechnol. Appl. Biochem., vol. 59, no. 2, pp. 77-87, 2012. [http://dx.doi.org/10.1002/bab.1014] [PMID: 23586788]

[112] M. Serra, C. Brito, C. Correia, and P.M. Alves, "Process engineering of human pluripotent stem cells for clinical application", Trends Biotechnol., vol. 30, no. 6, pp. 350-359, 2012.

[http://dx.doi.org/10.1016/j.tibtech.2012.03.003] [PMID: 22541338]

[113] C.K. Kwok, Y. Ueda, A. Kadari, K. Günther, S. Ergün, A. Heron, A.C. Schnitzler, M. Rook, and F. Edenhofer, "Scalable stirred suspension culture for the generation of billions of human induced pluripotent stem cells using single-use bioreactors", J. Tissue Eng. Regen. Med., vol. 12 , no. 2, pp. e1076-e1087, 2018 [http://dx.doi.org/10.1002/term.2435] [PMID: 28382727]

[114] S. Abbasalizadeh, M.R. Larijani, A. Samadian, and H. Baharvand, "Bioprocess development for mass production of size-controlled human pluripotent stem cell aggregates in stirred suspension bioreactor", Tissue Eng. Part C Methods, vol. 18, no. 11, pp. 831-851, 2012 .

[http://dx.doi.org/10.1089/ten.tec.2012.0161] [PMID: 22559864]

[115] D.E. Kehoe, D. Jing, L.T. Lock, and E.S. Tzanakakis, "Scalable stirred-suspension bioreactor culture of human pluripotent stem cells", Tissue Eng. Part A, vol. 16, no. 2, pp. 405-421, 2010. [http://dx.doi.org/10.1089/ten.tea.2009.0454] [PMID: 19739936]

[116] P.J. Kshitiz, J. Park, P. Kim, W. Helen, A.J. Engler, A. Levchenko, and D.H. Kim, "Control of stem cell fate and function by engineering physical microenvironments", Integr. Biol., vol. 4, no. 9, pp. 1008-1018, 2012

[http://dx.doi.org/10.1039/c2ib20080e] [PMID: 23077731]

[117] H.W. Leung, A. Chen, A.B.H. Choo, S. Reuveny, and S.K.W. Oh, "Agitation can induce differentiation of human pluripotent stem cells in microcarrier cultures", Tissue Eng. Part C Methods, vol. 17, no. 2, pp. 165-172, 2011.

[http://dx.doi.org/10.1089/ten.tec.2010.0320] [PMID: 20698747]

[118] J.J. Chalmers, "Cells and bubbles in sparged bioreactors", Cytotechnology, vol. 15, no. 1-3, pp. 311-320, 1994. [http://dx.doi.org/10.1007/BF00762406] [PMID: 7765946]

[119] Y.B. Bae, H.K. Jang, T.H. Shin, G. Phukan, T.T. Tran, G. Lee, W.R. Hwang, and J.M. Kim, "Microfluidic assessment of mechanical cell damage by extensional stress", Lab Chip, vol. 16, no. 1, pp. 96-103, 2016.

[http://dx.doi.org/10.1039/C5LC01006C] [PMID: 26621113]

[120] A. Fernandes-Platzgummer, M.M. Diogo, R.P. Baptista, C.L. da Silva, and J.M.S. Cabral, "Scale-up of mouse embryonic stem cell expansion in stirred bioreactors", Biotechnol. Prog., vol. 27, no. 5, pp. 1421-1432, 2011

[http://dx.doi.org/10.1002/btpr.658] [PMID: 21793233]

[121] Y. Chisti, "Animal-cell damage in sparged bioreactors", Trends Biotechnol., vol. 18, no. 10, pp. 420-432, 2000.

[http://dx.doi.org/10.1016/S0167-7799(00)01474-8] [PMID: 10998 508]

[122] M. Shafa, R. Krawetz, Y. Zhang, J.B. Rattner, A. Godollei, H.J. Duff, and D.E. Rancourt, "Impact of stirred suspension bioreactor culture on the differentiation of murine embryonic stem cells into cardiomyocytes", BMC Cell Biol., vol. 12, no. 1, p. 53, 2011. [http://dx.doi.org/10.1186/1471-2121-12-53] [PMID: 22168552]

[123] M. Vosough, E. Omidinia, M. Kadivar, M-A. Shokrgozar, B Pournasr, N. Aghdami, and H. Baharvand, "Generation of functional hepatocyte-like cells from human pluripotent stem cells in a scalable suspension culture", Stem Cells Dev., vol. 22, no. 20, pp. 2693-2705, 2013.

[http://dx.doi.org/10.1089/scd.2013.0088] [PMID: 23731381]

[124] M. Shafa, R. Krawetz, Y. Zhang, J.B. Rattner, A. Godollei, H.J. Duff, and D.E. Rancourt, "Impact of stirred suspension bioreactor culture on the differentiation of murine embryonic stem cells into cardiomyocytes", BMC Cell Biol., vol. 12, no. 1, p. 53, 2011. [http://dx.doi.org/10.1186/1471-2121-12-53] [PMID: 22168552]

[125] R.L. Carpenedo, C.Y. Sargent, and T.C. McDevitt, "Rotary suspension culture enhances the efficiency, yield, and homogeneity of embryoid body differentiation", Stem Cells, vol. 25, no. 9, pp. 2224-2234, 2007. [http://dx.doi.org/10.1634/stemcells.2006-0523] [PMID: 17585171]

[126] X. Lei, Z. Deng, H. Zhang, H. Zhao, J. Zhou, S. Liu, Q. Chen, L. Ning, Y. Cao, X. Wang, X. Zhang, and E. Duan, "Rotary suspension culture enhances mesendoderm differentiation of embryonic stem cells through modulation of Wnt/ $\beta$-catenin pathway", Stem Cell Rev., vol. 10 , no. 4, pp. 526-538, 2014. [http://dx.doi.org/10.1007/s12015-014-9511-6] [PMID: 24793926]

[127] C.Y. Sargent, G.Y. Berguig, and T.C. McDevitt, "Cardiomyogenic differentiation of embryoid bodies is promoted by rotary orbital suspension culture", Tissue Eng. Part A, vol. 15, no. 2, pp. 331-342, 2009.

[http://dx.doi.org/10.1089/ten.tea.2008.0145] [PMID: 19193130]

[128] J.N. Warnock, and M. Al-Rubeai, "Bioreactor systems for the production of biopharmaceuticals from animal cells", Biotechnol. Appl. Biochem., vol. 45, no. Pt 1, pp. 1-12, 2006. [http://dx.doi.org/10.1042/BA20050233] [PMID: 16764553]

[129] N. Freyer, F. Knöspel, N. Strahl, L. Amini, P. Schrade, S. Bachmann, G. Damm, D. Seehofer, F. Jacobs, M. Monshouwer, and K. Zeilinger, "Hepatic Differentiation of Human Induced Pluripotent Stem Cells in a Perfused Three-Dimensional Multicompartment Bioreactor", Biores. Open Access, vol. 5, no. 1, pp. 235-248, 2016. [http://dx.doi.org/10.1089/biores.2016.0027] [PMID: 27610270]

[130] F. Meier, N. Freyer, J. Brzeszczynska, F. Knöspel, L. Armstrong, M Lako, S. Greuel, G. Damm, E. Ludwig-Schwellinger, U. Deschl, J.A. 
Ross, M. Beilmann, and K. Zeilinger, "Hepatic differentiation of human iPSCs in different 3D models: A comparative study", Int. J. Mol. Med., vol. 40, no. 6, pp. 1759-1771, 2017. [PMID: 29039463]

[131] I. Roberts, S. Baila, R.B. Rice, M.E. Janssens, K. Nguyen, N. Moens, L. Ruban, D. Hernandez, P. Coffey, and C. Mason, "Scale-up of human embryonic stem cell culture using a hollow fibre bioreactor", Biotechnol. Lett., vol. 34, no. 12, pp. 2307-2315, 2012.

[http://dx.doi.org/10.1007/s10529-012-1033-1] [PMID: 22983716]

[132] MK Dame, and J Varani, "Recombinant collagen for animal productfree dextran microcarriers", Vitr Cell Dev Biol - Anim, vol. 44, no. 10, pp. 407-14, 2009.

[133] L.T. Lock, and E.S. Tzanakakis, "Expansion and differentiation of human embryonic stem cells to endoderm progeny in a microcarrier stirred-suspension culture", Tissue Eng. Part A, vol. 15, no. 8, pp. 2051-2063, 2009.

[http://dx.doi.org/10.1089/ten.tea.2008.0455] [PMID: 19196140]

[134] S.K.W. Oh, A.K. Chen, Y. Mok, X. Chen, U.M. Lim, A. Chin, A.B.H. Choo, and S. Reuveny, "Long-term microcarrier suspension cultures of human embryonic stem cells", Stem Cell Res. (Amst.), vol. 2, no. 3, pp. 219-230, 2009.

[http://dx.doi.org/10.1016/j.scr.2009.02.005] [PMID: 19393590]

[135] J-H.H. Park, R.A. Pérez, G-Z.Z. Jin, S-J.J. Choi, H-W.W. Kim, and I.B. Wall, "Microcarriers designed for cell culture and tissue engineering of bone", Tissue Eng. Part B Rev., vol. 19, no. 2, pp. 172-190, 2013.

[http://dx.doi.org/10.1089/ten.teb.2012.0432] [PMID: 23126371]

[136] B. Li, X. Wang, Y. Wang, W. Gou, X. Yuan, J. Peng, Q. Guo, and S. $\mathrm{Lu}$, "Past, present, and future of microcarrier-based tissue engineering", J. Orthop. Translat., vol. 3, no. 2, pp. 51-57, 2015. [http://dx.doi.org/10.1016/j.jot.2015.02.003] [PMID: 30035040]

[137] A.M. Fernandes, P.A.N. Marinho, R.C. Sartore, B.S. Paulsen, R.M. Mariante, L.R. Castilho, and S.K. Rehen, "Successful scale-up of human embryonic stem cell production in a stirred microcarrier culture system", Braz. J. Med. Biol. Res., vol. 42, no. 6, pp. 515-522, 2009. [http://dx.doi.org/10.1590/S0100-879X2009000600007] [PMID: 194 48900]

[138] A.K.L. Chen, X. Chen, A.B.H. Choo, S. Reuveny, and S.K.W. Oh, "Critical microcarrier properties affecting the expansion of undifferentiated human embryonic stem cells", Stem Cell Res. (Amst.), vol. 7, no. 2, pp. 97-111, 2011

[http://dx.doi.org/10.1016/j.scr.2011.04.007] [PMID: 21763618]

[139] Y. Fan, M. Hsiung, C. Cheng, and E.S. Tzanakakis, "Facile engineering of xeno-free microcarriers for the scalable cultivation of human pluripotent stem cells in stirred suspension", Tissue Eng. Part A, vol. 20, no. 3-4, pp. 588-599, 2014.

[PMID: 24098972]

[140] H. Uludag, P. De Vos, and P.A. Tresco, "Technology of mammalian cell encapsulation", $A d v$. Drug Deliv. Rev., vol. 42, no. 1-2, pp. 29-64, 2000.

[http://dx.doi.org/10.1016/S0169-409X(00)00053-3] [PMID: 10942 814]

[141] N. Siti-Ismail, A.E. Bishop, J.M. Polak, and A. Mantalaris, "The benefit of human embryonic stem cell encapsulation for prolonged feeder-free maintenance", Biomaterials, vol. 29, no. 29, pp. 3946-3952, 2008.

[http://dx.doi.org/10.1016/j.biomaterials.2008.04.027] [PMID: 1863 9332]

[142] I. Horiguchi, M.M. Chowdhury, Y. Sakai, and Y. Tabata, "Proliferation, morphology, and pluripotency of mouse induced pluripotent stem cells in three different types of alginate beads for mass production", Biotechnol. Prog., vol. 30, no. 4, pp. 896-904, 2014. [http://dx.doi.org/10.1002/btpr.1891] [PMID: 24585713]

[143] P. Kerscher, I.C. Turnbull, A.J. Hodge, J. Kim, D. Seliktar, C.J. Easley, K.D. Costa, and E.A. Lipke, "Direct hydrogel encapsulation of pluripotent stem cells enables ontomimetic differentiation and growth of engineered human heart tissues", Biomaterials, vol. 83, pp. 383-395, 2016.

[http://dx.doi.org/10.1016/j.biomaterials.2015.12.011] [PMID: 2682 6618]

[144] S. Gerecht, J.A. Burdick, L.S. Ferreira, S.A. Townsend, R. Langer, and G. Vunjak-Novakovic, "Hyaluronic acid hydrogel for controlled self-renewal and differentiation of human embryonic stem cells", Proc. Natl. Acad. Sci. USA, vol. 104, no. 27, pp. 11298-11303, 2007. [http://dx.doi.org/10.1073/pnas.0703723104] [PMID: 17581871]

[145] I. Horiguchi, and Y. Sakai, "Alginate Encapsulation of Pluripotent Stem Cells Using a Co-axial Nozzle", J. Vis. Exp., no. 101, p. e52835,
2015.

[PMID: 26168084]

[146] J.L. Wilson, M.A. Najia, R. Saeed, and T.C. McDevitt, "Alginate encapsulation parameters influence the differentiation of microencapsulated embryonic stem cell aggregates", Biotechnol. Bioeng., vol. 111, no. 3, pp. 618-631, 2014. [http://dx.doi.org/10.1002/bit.25121] [PMID: 24166004]

[147] S.K.W. Oh, W.J. Fong, Y. Teo, H.L. Tan, J. Padmanabhan, A.C.P. Chin, and A.B.H. Choo, "High density cultures of embryonic stem cells", Biotechnol. Bioeng., vol. 91, no. 5, pp. 523-533, 2005. [http://dx.doi.org/10.1002/bit.20650] [PMID: 16044469]

[148] Y. Wang, B.K. Chou, S. Dowey, C. He, S. Gerecht, and L. Cheng, "Scalable expansion of human induced pluripotent stem cells in the defined xeno-free E8 medium under adherent and suspension culture conditions", Stem Cell Res. (Amst.), vol. 11, no. 3, pp. 1103-1116, 2013.

[http://dx.doi.org/10.1016/j.scr.2013.07.011] [PMID: 23973800]

[149] Y. Wang, B-K. Chou, S. Dowey, C. He, S. Gerecht, and L. Cheng, "Scalable expansion of human induced pluripotent stem cells in the defined xeno-free E8 medium under adherent and suspension culture conditions", Stem Cell Res. (Amst.), vol. 11, no. 3, pp. 1103-1116, 2013.

[http://dx.doi.org/10.1016/j.scr.2013.07.011] [PMID: 23973800]

[150] X.S. Yue, M. Fujishiro, C. Nishioka, T. Arai, E. Takahashi, J.S. Gong, T. Akaike, and Y. Ito, "Feeder cells support the culture of induced pluripotent stem cells even after chemical fixation", PLoS One, vol. 7 , no. 3 , p. e32707, 2012

[http://dx.doi.org/10.1371/journal.pone.0032707] [PMID: 22396791]

[151] C. Tamm, S. Pijuan Galitó, and C. Annerén, "A comparative study of protocols for mouse embryonic stem cell culturing", PLoS One, vol. 8, no. 12 , p. e 81156,2013

[http://dx.doi.org/10.1371/journal.pone.0081156] [PMID: 24339907]

[152] K. Si-Tayeb, F.K. Noto, M. Nagaoka, J. Li, M.A. Battle, C. Duris, P.E. North, S. Dalton, and S.A. Duncan, "Highly efficient generation of human hepatocyte-like cells from induced pluripotent stem cells", Hepatology, vol. 51, no. 1, pp. 297-305, 2010. [http://dx.doi.org/10.1002/hep.23354] [PMID: 19998274]

[153] A.M. Craft, J.S. Rockel, Y. Nartiss, R.A. Kandel, B.A. Alman, and G.M. Keller, "Generation of articular chondrocytes from human pluripotent stem cells", Nat. Biotechnol., vol. 33, no. 6, pp. 638-645, 2015 .

[http://dx.doi.org/10.1038/nbt.3210] [PMID: 25961409]

[154] J. Chal, M. Oginuma, Z. Al Tanoury, B. Gobert, O. Sumara, A. Hick, F. Bousson, Y. Zidouni, C. Mursch, P. Moncuquet, O. Tassy, S. Vincent, A. Miyanari, A. Bera, J.M. Garnier, G. Guevara, M. Hestin, L. Kennedy, S. Hayashi, B. Drayton, T. Cherrier, B. Gayraud-Morel, E. Gussoni, F. Relaix, S. Tajbakhsh, and O. Pourquié, "Differentiation of pluripotent stem cells to muscle fiber to model Duchenne muscular dystrophy", Nat. Biotechnol., vol. 33, no. 9, pp. 962-969, 2015.

[http://dx.doi.org/10.1038/nbt.3297] [PMID: 26237517]

[155] TA Longmire, L Ikonomou, F Hawkins, C Christodoulou, Y Cao, C Jean, LW Kwok, H Mou, J Rajagopal, SS Shen, AA Dowton, M Serra, and DJ Weiss, "Efficient derivation of purified lung and thyroid progenitors from embryonic stem cells",

[156] N. Ozeki, M. Mogi, R. Kawai, H. Yamaguchi, T. Hiyama, K. Nakata, and H. Nakamura, "Mouse-induced pluripotent stem cells differentiate into odontoblast-like cells with induction of altered adhesive and migratory phenotype of integrin", PLoS One, vol. 8, no. 11, p. e80026, 2013.

[http://dx.doi.org/10.1371/journal.pone.0080026] [PMID: 24244598]

[157] H. Wang, Y. Xi, Y. Zheng, X. Wang, and A.J. Cooney, "Generation of electrophysiologically functional cardiomyocytes from mouse induced pluripotent stem cells", Stem Cell Res. (Amst.), vol. 16, no. 2, pp. 522-530, 2016.

[http://dx.doi.org/10.1016/j.scr.2016.02.032] [PMID: 26972055]

[158] S. Konagaya, T. Ando, T. Yamauchi, H. Suemori, and H. Iwata, "Long-term maintenance of human induced pluripotent stem cells by automated cell culture system", Sci. Rep., vol. 5, p. 16647, 2015. [http://dx.doi.org/10.1038/srep16647] [PMID: 26573336]

[159] D. Paull, A. Sevilla, H. Zhou, A.K. Hahn, H. Kim, C. Napolitano, A. Tsankov, L. Shang, K. Krumholz, P. Jagadeesan, C.M. Woodard, B. Sun, T. Vilboux, M. Zimmer, E. Forero, D.N. Moroziewicz, H. Martinez, M.C. Malicdan, K.A. Weiss, L.B. Vensand, C.R. Dusenberry, H. Polus, K.T. Sy, D.J. Kahler, W.A. Gahl, S.L. Solomon, S. Chang, A. Meissner, K. Eggan, and S.A. Noggle, "Automated, highthroughput derivation, characterization and differentiation of induced pluripotent stem cells", Nat. Methods, vol. 12, no. 9, pp. 885-892, 
2015.

[http://dx.doi.org/10.1038/nmeth.3507] [PMID: 26237226]

[160] W. Hussain, N. Moens, F.S. Veraitch, D. Hernandez, C. Mason, and G.J. Lye, "Reproducible culture and differentiation of mouse embryonic stem cells using an automated microwell platform", Biochem. Eng. J., vol. 77, no. 100, pp. 246-257, 2013. [http://dx.doi.org/10.1016/j.bej.2013.05.008] [PMID: 23956681]

[161] R.J. Thomas, D. Anderson, A. Chandra, N.M. Smith, L.E. Young, D. Williams, and C. Denning, "Automated, scalable culture of human embryonic stem cells in feeder-free conditions", Biotechnol. Bioeng., vol. 102, no. 6, pp. 1636-1644, 2009.

[http://dx.doi.org/10.1002/bit.22187] [PMID: 19062183]

[162] H Koike, K Kubota, K Sekine, T Takebe, R Ouchi, Y Zheng, and Y Ueno, "Establishment of automated culture system for murine induced pluripotent stem cells",

[http://dx.doi.org/10.1186/1472-6750-12-81]

[163] V.C. Chen, and L.A. Couture, "The suspension culture of undifferentiated human pluripotent stem cells using spinner flasks", Methods Mol. Biol., vol. 1283, pp. 13-21, 2015.

[http://dx.doi.org/10.1007/7651_2014_118] [PMID: 25537838]

[164] B. Abecasis, T. Aguiar, É. Arnault, R. Costa, P. Gomes-Alves, A. Aspegren, M. Serra, and P.M. Alves, "Expansion of 3D human induced pluripotent stem cell aggregates in bioreactors: Bioprocess intensification and scaling-up approaches", J. Biotechnol., vol. 246, pp. 81-93, 2017.

[http://dx.doi.org/10.1016/j.jbiotec.2017.01.004] [PMID: 28131858]

[165] M. Shafa, K. Sjonnesen, A. Yamashita, S. Liu, M. Michalak, M.S. Kallos, and D.E. Rancourt, "Expansion and long-term maintenance of induced pluripotent stem cells in stirred suspension bioreactors", $J$. Tissue Eng. Regen. Med., vol. 6, no. 6, pp. 462-472, 2012. [http://dx.doi.org/10.1002/term.450] [PMID: 21761573]

[166] A. Teo, A. Mantalaris, K. Song, and M. Lim, "A novel perfused rotary bioreactor for cardiomyogenesis of embryonic stem cells", Biotechnol. Lett., vol. 36, no. 5, pp. 947-960, 2014.

[http://dx.doi.org/10.1007/s10529-014-1456-y] [PMID: 24652542]

[167] S Rungarunlert, N Klincumhom, MK Pirity, and A Dinnyes, "Enhanced cardiac differentiation of mouse embryonic stem cells by use of the slow-turning, lateral vessel ( STLV) bioreactor",

[168] A.T-L. Lam, A.K-L. Chen, J. Li, W.R. Birch, S. Reuveny, and S.K-W. $\mathrm{Oh}$, "Conjoint propagation and differentiation of human embryonic stem cells to cardiomyocytes in a defined microcarrier spinner culture", Stem Cell Res. Ther., vol. 5, no. 5, p. 110, 2014. [http://dx.doi.org/10.1186/scrt498] [PMID: 25223792]

[169] R. Olmer, L. Engels, A. Usman, S. Menke, M.N.H. Malik, F. Pessler, G. Göhring, D. Bornhorst, S. Bolten, S. Abdelilah-Seyfried, T. Scheper, H. Kempf, R. Zweigerdt, and U. Martin, "Differentiation of Human Pluripotent Stem Cells into Functional Endothelial Cells in Scalable Suspension Culture", Stem Cell Reports, vol. 10, no. 5, pp. 1657-1672, 2018.

[http://dx.doi.org/10.1016/j.stemcr.2018.03.017] [PMID: 29681541]

[170] Y.S. Hwang, J. Cho, F. Tay, J.Y.Y. Heng, R. Ho, S.G. Kazarian, D.R. Williams, A.R. Boccaccini, J.M. Polak, and A. Mantalaris, "The use of murine embryonic stem cells, alginate encapsulation, and rotary microgravity bioreactor in bone tissue engineering", Biomaterials, vol. 30, no. 4, pp. 499-507, 2009.

[http://dx.doi.org/10.1016/j.biomaterials.2008.07.028] [PMID: 1897 7027]

[171] J Come, X Nissan, L Aubry, J Tournois, M Girard, AL Perrier, M Peschanski, and M Cailleret, "Improvement of culture conditions of human embryoid bodies using a controlled perfused and dialyzed bioreactor system",
[172] F. Knöspel, N. Freyer, M. Stecklum, J.C. Gerlach, and K. Zeilinger, "Periodic harvesting of embryonic stem cells from a hollow-fiber membrane based four-compartment bioreactor", Biotechnol. Prog., vol. 32 , no. 1, pp. 141-151, 2016.

[http://dx.doi.org/10.1002/btpr.2182] [PMID: 26486457]

[173] N. Amimoto, H. Mizumoto, K. Nakazawa, H. Ijima, K. Funatsu, and T. Kajiwara, "Hepatic differentiation of mouse embryonic stem cells and induced pluripotent stem cells during organoid formation in hollow fibers", Tissue Eng. Part A, vol. 17, no. 15-16, pp. 2071-2078, 2011.

[http://dx.doi.org/10.1089/ten.tea.2010.0689] [PMID: 21457096]

[174] A.M. Fernandes, T.G. Fernandes, M.M. Diogo, C.L. da Silva, D. Henrique, and J.M.S. Cabral, "Mouse embryonic stem cell expansion in a microcarrier-based stirred culture system", J. Biotechnol., vol. 132, no. 2, pp. 227-236, 2007. [http://dx.doi.org/10.1016/j.jbiotec.2007.05.031] [PMID: 17644203]

[175] S.M. Badenes, T.G. Fernandes, C.A.V. Rodrigues, M.M. Diogo, and J.M.S. Cabral, "Scalable expansion of human-induced pluripotent stem cells in xeno-free microcarriers", Methods Mol. Biol., vol. 1283, pp. 23-29, 2015.

[http://dx.doi.org/10.1007/7651_2014_106] [PMID: 25108454]

[176] J. Bardy, A.K. Chen, Y.M. Lim, S. Wu, S. Wei, H. Weiping, K. Chan, S. Reuveny, and S.K.W. Oh, "Microcarrier suspension cultures for high-density expansion and differentiation of human pluripotent stem cells to neural progenitor cells", Tissue Eng. Part C Methods, vol. 19, no. 2, pp. 166-180, 2013.

[http://dx.doi.org/10.1089/ten.tec.2012.0146] [PMID: 22834957]

[177] L.T. Lock, and E.S. Tzanakakis, "Expansion and differentiation of human embryonic stem cells to endoderm progeny in a microcarrier stirred-suspension culture", Tissue Eng. Part A, vol. 15, no. 8, pp. 2051-2063, 2009.

[http://dx.doi.org/10.1089/ten.tea.2008.0455] [PMID: 19196140]

[178] S-J. Lu, T. Kelley, Q. Feng, A. Chen, S. Reuveny, R. Lanza, and S.K. $\mathrm{Oh}$, "3D microcarrier system for efficient differentiation of human pluripotent stem cells into hematopoietic cells without feeders and serum [corrected]", Regen. Med., vol. 8, no. 4, pp. 413-424, 2013. [http://dx.doi.org/10.2217/rme.13.36] [PMID: 23826696]

[179] Y. Park, Y. Chen, L. Ordovas, and C.M. Verfaillie, "Hepatic differentiation of human embryonic stem cells on microcarriers", $J$. Biotechnol., vol. 174, no. 1, pp. 39-48, 2014.

[http://dx.doi.org/10.1016/j.jbiotec.2014.01.025] [PMID: 24480567]

[180] S. Ting, A. Chen, S. Reuveny, and S. Oh, "An intermittent rocking platform for integrated expansion and differentiation of human pluripotent stem cells to cardiomyocytes in suspended microcarrier cultures", Stem Cell Res. (Amst.), vol. 13, no. 2, pp. 202-213, 2014. [http://dx.doi.org/10.1016/j.scr.2014.06.002] [PMID: 25043964]

[181] M. Lecina, S. Ting, A. Choo, S. Reuveny, and S. Oh, "Scalable platform for human embryonic stem cell differentiation to cardiomyocytes in suspended microcarrier cultures", Tissue Eng. Part C Methods, vol. 16, no. 6, pp. 1609-1619, 2010. [http://dx.doi.org/10.1089/ten.tec.2010.0104] [PMID: 20590381]

[182] M. Chayosumrit, B. Tuch, and K. Sidhu, "Alginate microcapsule for propagation and directed differentiation of hESCs to definitive endoderm", Biomaterials, vol. 31, no. 3, pp. 505-514, 2010. [http://dx.doi.org/10.1016/j.biomaterials.2009.09.071] [PMID: 1983 3385]

[183] N. Wang, G. Adams, L. Buttery, F.H. Falcone, and S. Stolnik, "Alginate encapsulation technology supports embryonic stem cells differentiation into insulin-producing cells", J. Biotechnol., vol. 144, no. 4, pp. 304-312, 2009.

[http://dx.doi.org/10.1016/j.jbiotec.2009.08.008] [PMID: 19686786]

\section{(c) 2019 Torizal et al.}

This is an open access article distributed under the terms of the Creative Commons Attribution 4.0 International Public License (CC-BY 4.0), a copy of which is available at: https://creativecommons.org/licenses/by/4.0/legalcode. This license permits unrestricted use, distribution, and reproduction in any medium, provided the original author and source are credited. 